\title{
Cinnamaldehyde and Doxorubicin Co-Loaded Graphene Oxide Wrapped Mesoporous Silica Nanoparticles for Enhanced MCF-7 Cell Apoptosis
}

This article was published in the following Dove Press journal:

International Journal of Nanomedicine

\author{
Kai Dong* \\ Zhuang-Zhuang Zhao* \\ Jian Kang \\ Lei-Ruo Lin \\ Wen-Ting Chen \\ Jin-Xi Liu \\ Xiang-Long Wu \\ Ting-Li Lu
}

Key Laboratory for Space Bioscience and Biotechnology, School of Life Sciences, Northwestern Polytechnical University, Xi'an, Shaanxi, People's Republic of China

*These authors contributed equally to this work
Correspondence: Ting-Li Lu Key Laboratory for Space Bioscience and Biotechnology, School of Life Sciences, Northwestern Polytechnical University,

Xi'an, Shaanxi, People's Republic of China Tel/Fax +86-29-88460332

Email lutinglixinxin@nwpu.edu.cn
Background: Combined chemotherapy is often affected by the different physicochemical properties of chemotherapeutic drugs, which should be improved by the reasonable design of co-loaded preparations.

Purpose: A kind of simple but practical graphene oxide (GO) wrapped mesoporous silica nanoparticles (MSN) modified with hyaluronic acid (MSN@GO-HA) were developed for the co-delivery of cinnamaldehyde (CA) and doxorubicin (DOX), in order to enhance their combined treatment on tumor cells and reduce their application defects.

Methods: The $\mathrm{MSN}_{\mathrm{CA}} @ \mathrm{GO}_{\mathrm{DOX}}-\mathrm{HA}$ was constructed by $\mathrm{MSN}_{\mathrm{CA}}$ (loading $\mathrm{CA}$ via physical diffusion) and $\mathrm{GO}_{\mathrm{DOX}}-\mathrm{HA}$ (modified with $\mathrm{HA}$ and loading DOX via $\pi-\pi$ stacking) through the electrostatic adsorption, followed by the physicochemical characterization, serum stability and in vitro release study. Cytotoxicity on different cells was detected, followed by the tumor cell uptake tests. The intracellular reactive oxygen species (ROS) changes, mitochondrial functions and activities of caspase-3/-9 in MCF-7 cells were also evaluated, respectively.

Results: The $\mathrm{MSN}_{\mathrm{CA}} @ \mathrm{GO}_{\mathrm{DOX}}-\mathrm{HA}$ nanoparticles kept stable in FBS solution and achieved $\mathrm{pH}$-responsive release behavior, which was beneficial to increase the accumulation of CA and DOX in tumor cells to enhance the treatment. MSN $\mathrm{CA}_{\mathrm{C}} @ \mathrm{GO}_{\mathrm{DOX}}-\mathrm{HA}$ exerted higher cytotoxicity to MCF-7 human breast cancer cells than H9c2 cardiac myocyte cells, which were not only attributed to the active targeting to tumor cells by HA, but also related with the activation of intrinsic apoptotic pathway in MCF-7 cells induced by CA, which was mediated by the specific ROS signal amplification and the interference with mitochondrial function. Moreover, the efficacy of DOX was also enhanced by the above process.

Conclusion: The establishment of the $\mathrm{MSN}_{\mathrm{CA}} @ \mathrm{GO}_{\mathrm{DOX}}-\mathrm{HA}$ nanoparticles played a role in promoting strengths and restricting shortcomings of CA and DOX, thereby exerting their function and achieving efficient treatment against cancer.

Keywords: mesoporous silica nanoparticle, graphene oxide, hyaluronic acid, cinnamaldehyde, doxorubicin

\section{Introduction}

Chemotherapy is the main adjuvant treatment strategy for cancer, which not only improves the cure rates and reduces the local recurrence after operations of the patients at the early stage, but also alleviates the illness and prolongs the survival of the patients in the advanced stage. ${ }^{1}$ Chemotherapy is usually achieved through the 
combination of multiple therapeutic drugs, ${ }^{2,3}$ which promotes synergistic actions of agents with different mechanisms, enhances target selectivity and overcome the development of cancer drug resistance. However, differences in the physicochemical properties of these chemotherapeutic agents, such as solubility and chemical stability, usually result in the varying pharmacokinetics and different partitioning into the solid tumor tissues, thus hindering the effect of combined medication. ${ }^{4-7}$ Therefore, it is necessary to design appropriate drug delivery system to achieve the efficient loading and function optimization of chemotherapeutic agents with different properties.

Mesoporous silica nanoparticles (MSN) are a kind of inorganic nanoparticles, which have good chemical and thermal stability, large specific surface area and regular pore structures to achieve large loading capacity and good preservation of drugs. ${ }^{8}$ Moreover, MSN are also reported to be biocompatible and versatile chemistry for surface functionalization, thus achieving the active targeting, controlled or sustained release. ${ }^{10-12}$ Graphene oxide (GO) is a flexible two-dimensional carbon nanosheet, which has been widely employed as the basic building block of different nanocomposite drug delivery systems due to its good biocompatibility and highly functional surface. ${ }^{13,14}$ GO can load different kinds of therapeutic agents, such as nucleic acid drugs (DNA/RNA) and aromatic ring molecules (eg doxorubicin, camptothecin) through the noncovalent interactions (eg $\pi-\pi$ conjugation and hydrophobic effects), and release them in a pH-responsive manner in the acidic environment, such as the lysosomes and endosomes within tumor cells. ${ }^{15-18}$ Moreover, GO can act as a great gatekeeper to improve the ability of mesoporous nanoparticles to control their drug release behavior through appropriate wrapping on these nanoparticles. ${ }^{19}$

In this study, a kind of GO-wrapped MSN (MSN@GO) nanoparticles were constructed based on the special structure and drug-loading characteristics of MSN and GO, and employed for the co-delivery of cinnamaldehyde (CA), a small hydrophobic molecule with tumor therapeutic potential, and doxorubicin, a chemotherapeutic drug existed in the form of doxorubicin hydrochloride with good water solubility. CA is the major component (60-$75 \%$ ) of cinnamon bark (Cinnamomum spp., Lauraceae) essential oil, which has been found to process antitumor properties through the selective interference of mitochondrial function and ROS levels in tumor cells. ${ }^{20-22}$ DOX is a powerful anthracycline antibiotic, which mainly blocks
DNA synthesis and RNA transcription by embedding DNA double-stranded base pairs, so as to achieve the purpose of inhibiting tumor cell proliferation. Recently, several studies revealed that the combination of CA and DOX significantly promoted the apoptosis and necrosis of tumor cells, which was much better than either of them. ${ }^{23-25}$ However, the clinical application of CA is still limited due to its poor chemical stability and rapid clearance (short half-lives in human plasma) caused by the rapid oxidation of its aldehyde group, and the DOX also induced many side-effects (eg cardiotoxicity, skeletal muscle dysfunction and myelosuppression) due to the lack of effective tumor targeting mechanism. ${ }^{26-30}$ Therefore, in this study, CA was first introduced into the tunnel structure of aminated MSN (MSN-NH${ }_{2}$ ), and GO was modified with HA and loaded DOX via $\pi-\pi$ stacking. The CA-loaded MSN was then wrapped by the DOX-loaded GO-HA via the electrostatic adsorption to construct the $\mathrm{MSN}_{\mathrm{CA}}$ @ $\mathrm{GO}_{\text {Dox }}$-HA nanoparticles, which could achieve active targeting to tumor due to the affinity of HA to the CD44 receptor overexpressed on tumor cell surface. ${ }^{31}$ The preparation, dual-drugs loading, pH-responsive release of $\mathrm{MSN}_{\mathrm{CA}} @ \mathrm{GO}_{\mathrm{DOX}}-\mathrm{HA}$ nanoparticles and their apoptosis induction in MCF-7 cells are shown in Scheme 1 and investigated carefully in subsequent parts. We aimed to explore the best way to combine CA and DOX, that was to use a unique drug carrier to break through their limitations, and enhance their synergistic effects to improve the therapeutic effect on tumors.

\section{Materials and Methods Materials}

Hexadecyl trimethyl ammonium bromide (CTAB), triethanolamine, tetraethyl orthosilicate (TEOS), isopropanol, 3-aminopropyltriethoxysilane (APTES) and cinnamaldehyde (CA) were purchased from the heowns Co. Ltd. (Tianjin, China). Graphene oxide (GO), $N$-hydroxysuccinimide (NHS), 1-(3-Dimethylaminopropyl)-3-ethylcarbodiimide hydrochloride $(\mathrm{EDC} \cdot \mathrm{HCl})$, adipic dihydrazide $(\mathrm{ADH})$, hyaluronic acid (HA, $\quad 80-100 \mathrm{kDa}$ ) and doxorubicin hydrochloride $(\mathrm{DOX} \cdot \mathrm{HCl})$ were purchased from the Aladdin Chemistry Co. Ltd. (Shanghai, China). 3-(4,5-dimethylthiazol-2-yl)2,5-diphenyl-2h-tetrazolium bromide (MTT), DAPI, ROS assay kit (DCFH-DA), mitochondrial membrane potential assay kit with JC-1, ATP assay kit and Caspase-3, Caspase-9 activity kits were purchased from the Beyotime biotechnology 


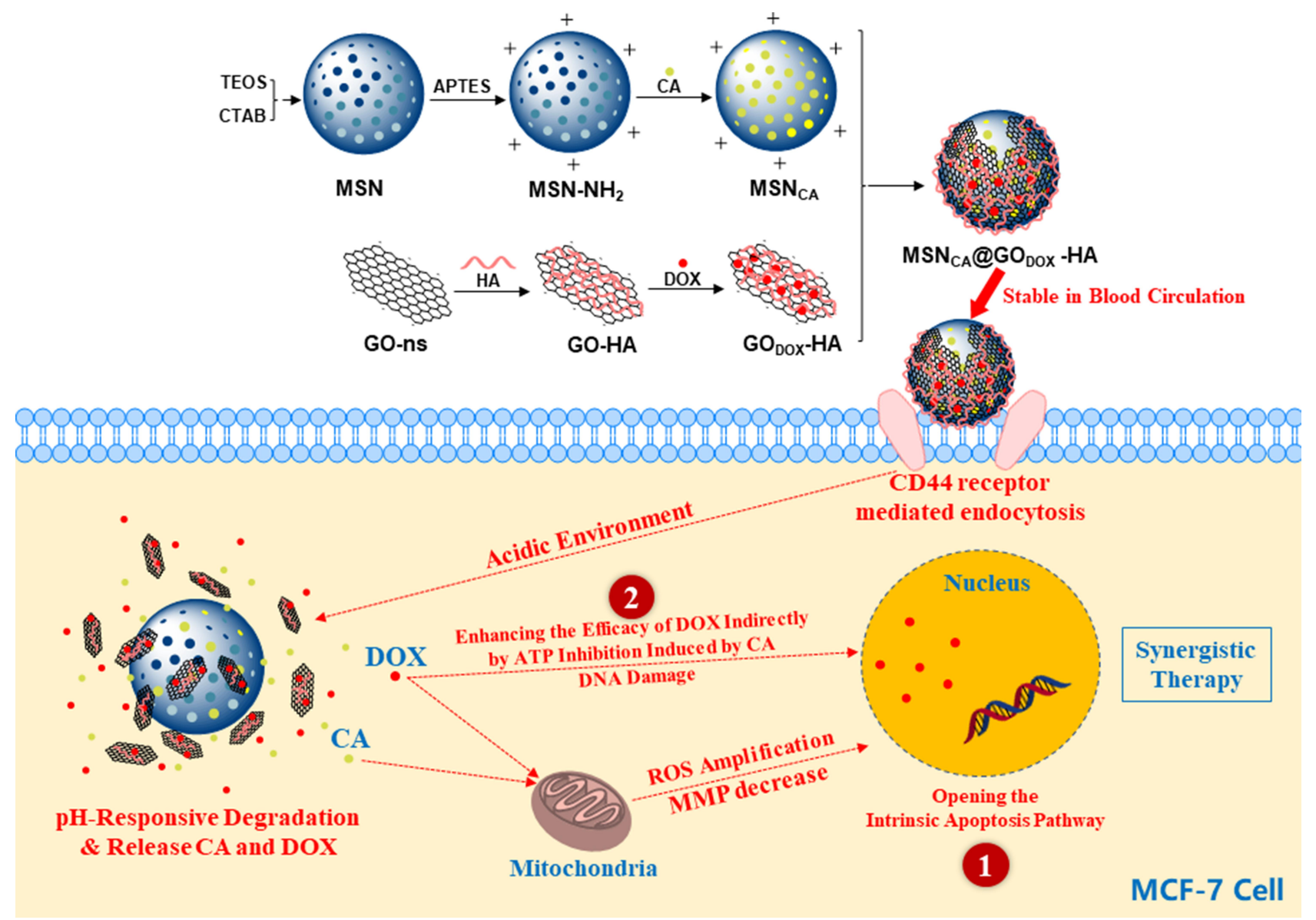

Scheme I Illustration of the preparation, dual-drugs loading, pH-responsive intracellular release of $M \mathrm{MN}_{\mathrm{CA}} @ \mathrm{GO}_{\mathrm{DOX}}-\mathrm{HA}_{\mathrm{A}}$ nanoparticles and their apoptosis induction in MCF-7 cells.

Co. Ltd. (Nantong, China). All other reagents were analytical or chromatographic grade.

The H9c2 rat cardiac myocyte cell line and MCF-7 human breast cancer cell line were purchased from the Cell Bank of Shanghai, Institute of Biochemistry and Cell Biology, Chinese Academy of Sciences (Shanghai, China). Cells were cultured in the DMEM medium under fully humidified conditions $\left(37^{\circ} \mathrm{C}\right.$ with $\left.5 \% \mathrm{CO}_{2}\right)$, supplemented with $10 \% \mathrm{FBS}, 100 \mathrm{IU} / \mathrm{mL}$ penicillin, and $100 \mathrm{mg} /$ $\mathrm{mL}$ streptomycin sulfate. Cells could be used in experiments when they were in the logarithmic phase of growth.

\section{Synthesis of Amino-Mesoporous Silica Nanoparticles (MSN-NH${ }_{2}$ )}

MSN was prepared according to the following steps: CTAB (2.07g) was first dissolved in the deionized water $(51.9 \mathrm{~mL})$ at $60^{\circ} \mathrm{C}$ with stirring. Then, the absolute ethanol $(12 \mathrm{~mL})$ and triethanolamine $(2.76 \mathrm{~g})$ were successively added to the transparent CTAB solution, followed by the dropwise addition of TEOS solution $(4.68 \mathrm{~mL})$ under the vigorous stirring. The mixed solution was stirred vigorously for $2 \mathrm{~h}$ at $60^{\circ} \mathrm{C}$. The resultant white solid was collected, washed with ethanol/deionized water for several times, and dried overnight in vacuum at $60^{\circ} \mathrm{C}$. The synthesized MSN powder $(1.0 \mathrm{~g})$ was resuspended in the acidic ethanol $(200 \mathrm{~mL}$, containing $10 \%$ concentrated hydrochloric acid, v/v). Then, the mixed solution was refluxed at $60^{\circ} \mathrm{C}$ for $24 \mathrm{~h}$ under vigorous stirring to remove the residual CTAB. The final products were collected by centrifuging $(10,000 \mathrm{rpm}$ for $10 \mathrm{~min})$, washed with ethanol/ deionized water for several times, and dried at $60^{\circ} \mathrm{C}$ overnight in vacuum.

The amine functionalization of MSN $\left(\mathrm{MSN}-\mathrm{NH}_{2}\right)$ was performed as follows: precisely weighed MSN $(0.2 \mathrm{~g})$ was added to a $500 \mathrm{~mL}$ round bottom flask (RBF). Isopropanol $(200 \mathrm{~mL})$ and APTES $(2 \mathrm{~mL})$ were successively added to the RBF, and the reaction was performed at a higher temperature $\left(80^{\circ} \mathrm{C}\right)$ for $24 \mathrm{~h}$, under the reflux and vigorous stirring condition using an oil bath. After finishing the 
reaction, the RBF was removed and cooled to room temperature. The $\mathrm{MSN}-\mathrm{NH}_{2}$ was collected by centrifuging (10,000rpm for $10 \mathrm{~min})$, washed with ethanol and deionized water for several times, and dried at $60^{\circ} \mathrm{C}$ overnight in vacuum.

\section{Synthesis of Hyaluronic Acid Modified Graphene Oxide Nanosheets (GO-HA)}

Precisely weighed GO powder $(0.1 \mathrm{~g})$ was dissolved in the deionized water $(10 \mathrm{~mL})$. The graphene oxide nanosheets (GO-ns) were obtained through the sonication cutting approach on the GO solution by an ultrasonic cell disruptor (1200E, Scientz, China). Several groups of GO solution were set up for different ultrasonic time, which was used to obtain the optimal hydrodynamic size of the GO-ns. The GO-HA was obtained by a two-step synthesis: in the synthesis of GO-ADH, GO-ns $(0.05 \mathrm{~g})$ was dispersed in the deionized water $(50 \mathrm{~mL})$. Then, NHS $(0.75 \mathrm{~g})$ and $\mathrm{EDC} \cdot \mathrm{HCl}$ $(0.25 \mathrm{~g})$ was successively added to the GO-ns solution. After adjusting the $\mathrm{pH}$ value to 5.76 by $1 \mathrm{M} \mathrm{NaOH}$ solution, the $\mathrm{ADH}(0.52 \mathrm{~g})$ was added to the mixed solution, and the reaction was performed at room temperature for $24 \mathrm{~h}$. The obtained product was first washed and centrifuged, then dialyzed in the deionized water to remove unreacted impurities (MWCO 3500), finally freeze-dried to obtain the ADH-modified GO (GO-ADH). To the synthesis of GOHA, HA $(0.015 \mathrm{~g})$ was dissolved in deionized water $(15 \mathrm{~mL})$. NHS $(0.112 \mathrm{~g})$ and $\mathrm{EDC} \cdot \mathrm{HCl}(0.037 \mathrm{~g})$ were successively added to the HA solution, and the $\mathrm{pH}$ value of the solution was adjusted to 5.60 by the $\mathrm{NaOH}$ solution (1M). Then, the GO-ADH was added to the mixed solution, and the reaction was performed at room temperature for $24 \mathrm{~h}$. The purification process of GO-HA was the same as the preparation of GO-ADH.

\section{Synthesis of $M S N_{C A} @ G O_{D O X}-H A$}

The synthesis of $\mathrm{MSN}_{\mathrm{CA}} @ \mathrm{GO}_{\mathrm{DOX}}-\mathrm{HA}$ was carried out in two steps. MSN and GO-HA were first employed to load $\mathrm{CA}$ and DOX, respectively, then mixed together to prepare $\mathrm{MSN}_{\mathrm{CA}} @ \mathrm{GO}_{\mathrm{DOx}}-\mathrm{HA}$. Briefly, the $\mathrm{MSN}-\mathrm{NH}_{2}$ powder $(0.01 \mathrm{~g})$ was added to the CA solution $(1 \mathrm{mg} / \mathrm{mL}$, $10 \mathrm{~mL}$, dissolved in methanol), followed by the stirring for $12 \mathrm{~h}$ at room temperature. ${ }^{32}$ The $\mathrm{MSN}_{\mathrm{CA}}$ was obtained by centrifuging $(10,000 \mathrm{rpm}$ for $30 \mathrm{~min})$, washed with deionized water, and dried at $60^{\circ} \mathrm{C}$ in vacuum. Moreover, DOX $\cdot \mathrm{HCl}$ solution $(1 \mathrm{mg} / \mathrm{mL}, 10 \mathrm{~mL}$, dissolved in deionized water) and GO-HA $(1 \mathrm{mg} / \mathrm{mL}, 5 \mathrm{~mL}$, dissolved in deionized water) solutions were mixed together, followed by stirring for $24 \mathrm{~h}$ at room temperature. After repeated centrifuging (10,000rpm for $30 \mathrm{~min})$ and washed with deionized water, the $\mathrm{GO}_{\mathrm{DOX}}-\mathrm{HA}$ was obtained through dialysis (MWCO 3500, in the deionized water) and lyophilization. Afterwards, the aqueous solutions of $\mathrm{MSN}_{\mathrm{CA}}$ and $\mathrm{GO}_{\mathrm{DOX}}-\mathrm{HA}$ with the concentration of $1 \mathrm{mg} / \mathrm{mL}$ (the volumes of both solutions were $10 \mathrm{~mL}$ ) were mixed and stirred at room temperature for $12 \mathrm{~h}$, then centrifuged $(10,000 \mathrm{rpm}$ for $30 \mathrm{~min})$, washed with deionized water and dried in vacuum at room temperature to obtain $\mathrm{MSN}_{\mathrm{CA}} @ \mathrm{GO}_{\mathrm{DOX}}-\mathrm{HA}$. The drug-loading coefficient (DL) and drug entrapment efficiency (EE) were employed to evaluate the drug-loading efficiency, which were calculated by the following equations, respectively:

DL $(\%)=$ Weight of the drug in carriers/Weight of the feeding carriers and drug $\times 100 \%$

EE $(\%)=$ Weight of the drug in carriers/Weight of the feeding drug $\times 100 \%$

\section{Serum Stability and in vitro Release}

The serum stability of $\mathrm{MSN}_{\mathrm{CA}} @ \mathrm{GO}_{\mathrm{DOX}}-\mathrm{HA}$ was detected by the dynamic light scattering (DLS). Briefly, aqueous solutions $(5 \mathrm{~mL})$ of $\mathrm{MSN}_{\mathrm{CA}}, \mathrm{MSN}_{\mathrm{CA}} @ \mathrm{GO}_{\mathrm{DOX}}$ and $\mathrm{MSN}_{\mathrm{CA}} @ \mathrm{GO}_{\mathrm{DOX}}-\mathrm{HA}$ were immersed in $50 \mathrm{~mL}$ deionized water containing fetal bovine serum (FBS, 25\%, v/v), respectively, and incubated in a shaker at $37^{\circ} \mathrm{C}$. At predetermined time intervals $(0,1,2,4,8,12$ and $24 \mathrm{~h}), 1 \mathrm{~mL}$ solution was withdrawn and immediately divided into two parts: one was detected with DLS (Malvern Zetasizer Naso ZS, Malvern, UK) to determine the changes in particle size and polydispersity index (PDI). The other was centrifugated and extracted with acetonitrile to measure the concentration of CA by a high-performance liquid chromatography (HPLC, Alliance, Waters, USA), in order to assess the escape rate of CA from different preparations, which were calculated by the following equation:

Escape rate $(\%)=$ Amount of released $\mathrm{CA} / \mathrm{CA}$ content in the nanoparticles $\times 100 \%$

The in vitro release behavior of $\mathrm{MSN}_{\mathrm{CA}} @ \mathrm{GO}_{\mathrm{DOx}}-\mathrm{HA}$ was investigated by the dialysis method. Specifically, pH5.0 and 7.4 phosphate buffers (PBS) were prepared as the release medium. The $\mathrm{MSN}_{\mathrm{CA}} @ \mathrm{GO}_{\mathrm{DOX}}-\mathrm{HA}$ power (10mg) was added to the dialysis bags (MWCO 3500), followed by adding $2 \mathrm{~mL}$ pH5.0 or pH7.4 PBS. Then, the dialysis bags were sealed and immersed in $8 \mathrm{~mL}$ of PBS 
solutions with corresponding $\mathrm{pH}$ values. The in vitro release experiment was carried out at $100 \mathrm{rpm}, 37^{\circ} \mathrm{C}$ in a shaker, and all solutions (excluding those in dialysis bags) were withdrawn and replenish the same volume of fresh solution. Samples were filtered through $0.22 \mu \mathrm{m}$ membrane filter and ultraviolet spectrophotometer (F2300, Shimadzu, Japan) and HPLC (Alliance, Waters, USA) were used to detect the concentration of DOX and CA in each sample. All samples were tested in triplicate and the results at each time point were divided by the initial value to obtain relative values.

\section{Characterization and Analysis}

The sizes and zeta potentials of different nanocarriers were measured by the DLS, using the Malvern Zetasizer Nano ZS (Malvern instruments, Malvern, UK). A transmission electron microscope (TEM, Talos F200X, ThermoFisher Scientific, USA) was used to investigate the morphological features of MSN, MSN-NH $\mathrm{N}_{2}, \mathrm{GO}, \mathrm{GO}-\mathrm{ns}, \mathrm{MSN} @ \mathrm{GO}$ and MSN@GO-HA, and the energy dispersive spectrometer (EDS) analysis was performed on MSN-NH $2, \mathrm{MSN} @ \mathrm{GO}$ and MSN@GO-HA. Moreover, the element composition in MSN@GO-HA was also investigated by the X-ray photoelectron spectroscopy (XPS, AXIS Supra, Shimadzu KRATOS, Japan). The structural differences between MSN and $\mathrm{MSN}-\mathrm{NH}_{2}, \mathrm{GO}$ and GO-HA were characterized by the fourier transform infrared spectroscopy (FTIR, Bruker ALPHA-T instrument, Germany). The surface analysis of MSN and $\mathrm{MSN}-\mathrm{NH}_{2}$ was executed by the nitrogen $\left(\mathrm{N}_{2}\right)$ sorption isotherms on a sorptometer (ASAP 2020, Micromeritics, US). The Brunauer Emmett Teller (BET) method was used for the calculation of surface area and the pore size distribution was calculated by the BJH method.

The concentration of CA was detected by the HPLC. Specifically, the mobile phase was acetonitrile/water (43/ $57, \mathrm{v} / \mathrm{v}$ ) with the $1.0 \mathrm{~mL} / \mathrm{min}$ flow rate, using a $\mathrm{C}_{18}$ BDS column $(5 \mu \mathrm{m}, 250 \times 4.6 \mathrm{~mm}$, Thermo Fisher Scientific, USA). A calibration curve was used to assess the linearity of CA concentration, namely plotting peak areas of analytes versus CA concentrations $\left(5 \times 10^{-2}\right.$ to $\left.10 \mu \mathrm{g} / \mathrm{mL}\right)$. Samples were detected at the wavelength of $290 \mathrm{~nm}$. The concentration of DOX was detected by an ultraviolet spectrophotometer (Rt2100, Rayto, US). The detection wavelength was fixed at $480 \mathrm{~nm}$ after the full-wavelength scanning. The linearity of DOX concentration was assessed by a calibration curve, which was obtained by plotting absorbances of analytes versus DOX concentrations $\left(5 \times 10^{-1}\right.$ to $\left.100 \mu \mathrm{g} / \mathrm{mL}\right)$. The concentration of CA or DOX in each sample was quantified by comparing the peak area or absorbance with the standard curve.

\section{Cytotoxicity}

H9c2 and MCF-7 cells were employed to detect the cytotoxicity of $\mathrm{MSN}_{\mathrm{CA}} @ \mathrm{GO}_{\mathrm{DOX}}-\mathrm{HA}$ by MTT assay. Since $\mathrm{CA}$ and DOX were simultaneously loaded in the MSN@GO-HA, this work compared MSN $\mathrm{CA}_{0} \mathrm{GO}_{\mathrm{DOX}^{-}}$ HA with different CA or DOX preparations to investigate the cytotoxicity in different cells. Specifically, H9c2 and MCF-7 cells in the logarithmic growth phase were seeded in the 96 -well plates $\left(5 \times 10^{3}\right.$ cells per well) and incubated for $24 \mathrm{~h}$ at $37^{\circ} \mathrm{C}$. Then, the supernatant was discarded and cells were incubated with different CA or DOX preparations. In the cytotoxicity investigation of different CA preparations, the culture medium was replaced by the MSN $\mathrm{CA}_{\mathrm{A}} @ \mathrm{GO}_{\mathrm{DOX}}-\mathrm{HA}, \mathrm{MSN}_{\mathrm{CA}} @ \mathrm{GO}_{\mathrm{DOX}}, \mathrm{MSN}_{\mathrm{CA}}$ and free CA of various concentrations $(0.1-200 \mu \mathrm{g} / \mathrm{mL}$, diluted by the growth medium according to the concentration of the free CA). In the cytotoxicity investigation of different DOX preparations, the culture medium was replaced by the $\mathrm{MSN}_{\mathrm{CA}} @ \mathrm{GO}_{\mathrm{DOX}}-\mathrm{HA}, \mathrm{MSN}_{\mathrm{CA}}$ (a) $\mathrm{GO}_{\mathrm{DOX}}, \mathrm{GO}_{\mathrm{DOX}}$ and free DOX solutions of various concentrations $(0.2-40 \mu \mathrm{g} / \mathrm{mL}$, diluted by the growth medium according to the concentration of the free DOX). After $24 \mathrm{~h}$ incubation, the supernatant was discarded and MTT solution was added to each well for another $4 \mathrm{~h}$ incubation, allowing living cells to reduce MTT into formazan crystals (from yellow to purple). Then, medium in each well was replaced by DMSO $(150 \mu \mathrm{g})$ at the predetermined time to dissolve the formazan crystals. After incubated for $10 \mathrm{~min}$, the absorbance at $570 \mathrm{~nm}$ was detected by an enzyme-linked immunosorbent assay microplate reader (Bio-Rad). The cytotoxicity was quantified as the cell viability, which was calculated according to the following equation:

Cell viability $(\%)=$ Absorption of test group/ Absorption of control group $\times 100 \%$

\section{Tumor Cells Uptake}

The tumor cell uptake experiments of different nanocarriers were qualitatively investigated by an inverted fluorescence microscope (Leica DMIL, Germany) and quantitatively investigated by a flow cytometry (FACSCalibur, BD, USA) using MCF-7 cells through observing and analyzing the fluorescence intensity of DOX. For the qualitative observation, MCF-7 cells were 
seeded in 6-well plates $\left(2 \times 10^{5}\right.$ cells per well), and each well was covered with a glass coverslip. The supernatant was replaced with free DOX, GO DOX, MSN@GO $\mathrm{GO}_{\mathrm{DOX}}$ or MSN@ $\mathrm{GO}_{\text {DOx }}-\mathrm{HA}$ growth medium solution $(10 \mu \mathrm{g} / \mathrm{mL}$, diluted by the growth medium according to the concentration of the free DOX) after $24 \mathrm{~h}$, and the incubation was continued for another $4 \mathrm{~h}$. At the predetermined time, coverslips with cells were taken off, washed with ice-cold PBS, treated with paraformaldehyde $(4 \%, 1 \mathrm{~mL})$ in empty wells (15min), finally adding DAPI to counterstain cell nucleus (5min). An inverted fluorescence microscope (Leica DMIL, Germany) was employed to analyze the final sample after cells were washed with ice-cold PBS to remove the residual DAPI. For the quantitative analysis, MCF-7 cells were seeded in 12 -well plates $\left(1 \times 10^{5}\right.$ cells per well). The supernatant was replaced with free DOX, GO DOX, MSN@GO $\mathrm{GOX}_{\text {Dox }}$ or MSN@GO $\mathrm{GOX}_{\text {DOX }}$-HA growth medium solution $(10 \mu \mathrm{g} / \mathrm{mL}$, diluted by the growth medium according to the concentration of the free DOX) after $24 \mathrm{~h}$, and the incubation was continued for another $4 \mathrm{~h}$. At the predetermined time, cells were digested by trypsin, then harvested, centrifuged and resuspended in PBS to detect the fluorescence by a flow cytometry (FACSCalibur, BD, USA).

Furthermore, in order to demonstrate that $\mathrm{MSN}_{\mathrm{CA}}$ @ $\mathrm{GO}_{\mathrm{DOX}}$-HA entering MCF-7 cells was mainly mediated by the CD44 receptor-mediated active endocytosis, the competitive inhibition assay was employed using free $\mathrm{HA}$ as the competitive inhibitor to investigate its effect on the uptake of $\mathrm{MSN}_{\mathrm{CA}} @ \mathrm{GO}_{\mathrm{DOx}}-\mathrm{HA}$. Briefly, MCF-7 cells in the logarithmic growth phase were seeded in the 24 -well plates $\left(1 \times 10^{5}\right.$ cells per well) and incubated for $24 \mathrm{~h}$ at $37^{\circ} \mathrm{C}$. After discarding the culture medium, $200 \mu \mathrm{L}$ HA solution of different concentrations (diluted with DMEM without serum) was added and pre-incubated for 30min. Then, $200 \mu \mathrm{L}$ free DOX, GO $\mathrm{DOX}_{\mathrm{X}}, \mathrm{MSN}_{\mathrm{CA}} @ \mathrm{GO}_{\mathrm{DOX}}$ and $\mathrm{MSN}_{\mathrm{CA}} @ \mathrm{GO}_{\mathrm{DOX}}-\mathrm{HA}$ were added, respectively, finally fixing the concentration of $\mathrm{HA}$ at 50,100 and $200 \mu \mathrm{g} / \mathrm{mL}$, respectively, while the concentration of DOX in these preparations was $10 \mu \mathrm{g} / \mathrm{mL}$. After incubated for $4 \mathrm{~h}$, cells were washed with ice-cold PBS, treated with RIPA cell lysate $(150 \mu \mathrm{L})$ followed by incubated for $10 \mathrm{~min}$ at $37^{\circ} \mathrm{C}$. The concentration of DOX in each sample was determined according to the cytotoxicity test, and normalized by the protein content in each sample using a BCA kit. The uptake index was defined as the ratio of the weight of DOX absorbed by cells to the weight of feeding DOX in each sample.

\section{Detection of Intracellular ROS Level in}

\section{Tumor Cells}

The effects of different CA and DOX preparations on the variation of intracellular ROS levels in MCF-7 cells were detected by the ROS probe, 2',7'- dichlorofluorescein (DCFH-DA). Specifically, MCF-7 cells in the logarithmic growth phase were seeded in the 24 -well plates $\left(1 \times 10^{5}\right.$ cells per well) and incubated for $24 \mathrm{~h}$ at $37^{\circ} \mathrm{C}$. Then, the supernatant was discarded and cells were washed with icecold PBS for three times. Afterwards, different CA preparations $\left(\mathrm{MSN}_{\mathrm{CA}} @ \mathrm{GO}_{\mathrm{DOX}}-\mathrm{HA}, \mathrm{MSN}_{\mathrm{CA}} @ \mathrm{GO}_{\mathrm{DOX}}\right.$, $\mathrm{MSN}_{\mathrm{CA}}$ and free CA, adjusted to $200 \mu \mathrm{g} / \mathrm{mL}$ according to the concentration of free $\mathrm{CA}$ ) or DOX preparations (MSN ${ }_{\mathrm{CA}} @ \mathrm{GO}_{\mathrm{DOX}}-\mathrm{HA}, \mathrm{MSN}_{\mathrm{CA}} @ \mathrm{GO}_{\mathrm{DOX}}, \mathrm{GO}_{\mathrm{DOX}}$ and free DOX solutions, adjusted to $40 \mu \mathrm{g} / \mathrm{mL}$ according to the concentration of free DOX) were added to incubate the cells for $8 \mathrm{~h}$ at $37^{\circ} \mathrm{C}$. Then, cells were washed with icecold PBS for three times. DCFH-DA diluted with blank culture medium was added to each well and incubated for $0.5 \mathrm{~h}$, followed by washed with ice-cold PBS, harvested, and resuspended in PBS to detect the fluorescence by a flow cytometry (FACSCalibur, BD, USA).

\section{Detection of Mitochondrial Function in Tumor Cells}

The mitochondrial membrane potential (MMP) of MCF-7 was detected by the lipophilic probe JC-1 $\left(5,5^{\prime}, 6,6^{\prime}\right.$ tetrachloro-1,1',3,3'-tetraethylene imidazolyl carbocyanine iodide) after treated with different CA or DOX preparations. The confluent cells $\left(5 \times 10^{5}\right.$ cells per well in 12 -well plates) were incubated with the culture medium containing different CA preparations $\left(\mathrm{MSN}_{\mathrm{CA}} @ \mathrm{GO}_{\mathrm{DOX}}-\mathrm{HA}, \mathrm{MSN}_{\mathrm{CA}}\right.$ (a) $\mathrm{GO}_{\mathrm{DOX}}, \mathrm{MSN}_{\mathrm{CA}}$ and free CA, adjusted to $200 \mu \mathrm{g} / \mathrm{mL}$ according to the concentration of free $\mathrm{CA}$ ) or DOX preparations $\left(\mathrm{MSN}_{\mathrm{CA}} @ \mathrm{GO}_{\mathrm{DOX}}-\mathrm{HA}, \mathrm{MSN}_{\mathrm{CA}} @ \mathrm{GO}_{\mathrm{DOX}}\right.$, $\mathrm{GO}_{\text {DOX }}$ and free DOX solutions, adjusted to $40 \mu \mathrm{g} / \mathrm{mL}$ according to the concentration of free DOX) for $8 \mathrm{~h}$. Then, the medium was removed and cells were washed with cold PBS, followed by trypsinized and suspended in diluted JC-1 staining solution $(500 \mu \mathrm{L})$ for $20 \mathrm{~min}$. After rinsing with physiological saline, cells were suspended in JC-1 staining buffer $(500 \mu \mathrm{L})$ to measure the fluorescence intensity by a flow cytometer (FACSCalibur, BD, USA). The measurement results were expressed as the average JC-1 red/green (R/G) signal intensity ratio.

Since ATP is produced in the process of biological oxidation in the inner membrane of mitochondria, whose 
function is directly affected by the change in the mitochondrial function. Therefore, the effects of different preparations on the ATP content in MCF-7 cells were also investigated. The selected cells were the same batch as those used for the mitochondrial MP detection. The confluent cells were incubated with the culture medium containing different CA preparations $\left(\mathrm{MSN}_{\mathrm{CA}} @ \mathrm{GO}_{\mathrm{DOX}}-\mathrm{HA}\right.$, $\mathrm{MSN}_{\mathrm{CA}} @ \mathrm{GO}_{\mathrm{DOX}}, \mathrm{MSN}_{\mathrm{CA}}$ and free CA, adjusted to $200 \mu \mathrm{g} / \mathrm{mL}$ according to the concentration of free CA) or DOX preparations $\left(\mathrm{MSN}_{\mathrm{CA}} @ \mathrm{GO}_{\mathrm{DOx}}-\mathrm{HA}, \quad \mathrm{MSN}_{\mathrm{CA}}\right.$ (a) $\mathrm{GO}_{\mathrm{DOX}}, \mathrm{GO}_{\mathrm{DOX}}$ and free DOX solutions, adjusted to $40 \mu \mathrm{g} / \mathrm{mL}$ according to the concentration of free DOX) for $2 \mathrm{~h}$. The culture medium was discarded at the predetermined time, and then, cells were washed and solubilized in cell lysates, followed by centrifugation $(12,000 \mathrm{~g})$ at $4^{\circ} \mathrm{C}$ for 10 mins to collect the supernatant, which were used for the ATP quantification by the luciferin/luciferase assay. An Ultra-Weak luminescence analyzer (Model BPCL, Guangzhou, China) was employed to measure the light emission of each sample, and the raw data were converted to the ATP concentration based on the standard calibration curve. The protein content in each sample detected by a BCA kit was employed to normalize the ATP content, and the blank medium was set as the control.

\section{Detection of Caspase-3 and Caspase- 9 Activities}

The Caspase-3 and Caspase-9 activity detections were performed by the Beyotime Caspase- 3 and Caspase- 9 activity assay kits according to the manufacturer's instructions in order to further investigate the influence mechanism of $\mathrm{MSN}_{\mathrm{CA}} @ \mathrm{GO}_{\mathrm{DOX}}-\mathrm{HA}$ on the intrinsic apoptosis pathway. Briefly, the confluent cells $\left(1 \times 10^{6}\right.$ cells per well in 6-well plates) were incubated with the culture medium containing different $\mathrm{CA}$ preparations $\left(\mathrm{MSN}_{\mathrm{CA}} @ \mathrm{GO}_{\mathrm{DOX}^{-}}\right.$ $\mathrm{HA}, \mathrm{MSN}_{\mathrm{CA}} @ \mathrm{GO}_{\mathrm{DOX}}, \mathrm{MSN}_{\mathrm{CA}}$ and free CA, adjusted to $40 \mu \mathrm{g} / \mathrm{mL}$ according to the concentration of free $\mathrm{CA}$ ) or DOX preparations $\left(\mathrm{MSN}_{\mathrm{CA}} @ \mathrm{GO}_{\mathrm{DOX}}, \mathrm{GO}_{\mathrm{DOX}}\right.$ and free DOX solutions, adjusted to $5 \mu \mathrm{g} / \mathrm{mL}$ according to the concentration of free DOX) for $24 \mathrm{~h}^{25}$ Subsequently, cells were trypsinized and centrifuged at 1000rpm, then lysed with lysis buffer $(50 \mu \mathrm{L})$ and incubated on ice for $15 \mathrm{~min}$. The protein content of cells was extracted by the centrifugation of lysates $(16,000-20,000 \mathrm{rpm})$ at $4^{\circ} \mathrm{C}$ for $10 \mathrm{~min}$. The substrate reaction buffers containing Caspase- 3 or Caspase-9 (2mM) were added separately to the supernatant and incubated for $1 \mathrm{~h}$ at $37^{\circ} \mathrm{C}$ (until the significant changes in color occurred). Then the absorbance was immediately measured at $405 \mathrm{~nm}$ by a plate reader (BioTek, USA). The protein content was determined by the Bradford method to normalize the activity of Caspase3 or Caspase-9, and the measurement results were expressed as the percent of control.

\section{Statistical Analysis}

All results were presented as the mean \pm standard deviation (SD). Statistical comparisons were evaluated by oneway analysis of variance and LSD test, with SPSS Statistical Software (v.22; IBM, Chicago, IL, USA). $P<0.05$ was considered as statistically significant.

\section{Results}

\section{Characterization of MSN and $\mathrm{MSN}-\mathrm{NH}_{2}$}

As shown in Figure 1A and B, the prepared MSN and MSN-NH$H_{2}$ exhibited homogenous spherical nanostructures, and their hydrodynamic sizes ranged from 70 to 80nm (Figure 1C). Moreover, their zeta potentials varied from $-17 \mathrm{mV}(\mathrm{MSN})$ to $19 \mathrm{mV}\left(\mathrm{MSN}-\mathrm{NH}_{2}\right)$ since the silanol groups on the surface of MSN were replaced by the amino groups, and the PDI also changed slightly (Figure 2A). Figure 2B shows the FTIR spectrum of $\mathrm{MSN}$ and $\mathrm{MSN}-\mathrm{NH}_{2}$. The new bending vibration peaks of $\mathrm{N}-\mathrm{H}$ bonds (existed in the $\mathrm{NH}_{2}$ groups of ATPES) appeared at 1634 and $1555 \mathrm{~cm}^{-1}$, and the stretching vibration peaks of $\mathrm{C}-\mathrm{H}$ bonds (existed in the $-\mathrm{CH}_{2}$ groups of ATPES) appeared at $2942 \mathrm{~cm}^{-1}$ confirmed the modification of MSN by APTES and was consistent with the description of related studies. ${ }^{33}$ The pore size distribution, pore volume and BET surface area were determined by the nitrogen adsorption/desorption measurements (Figure 2C, D and Table S1). The adsorption/desorption isotherms of MSN and $\mathrm{MSN}-\mathrm{NH}_{2}$ exhibited a typical IV isotherms curve, which was manifested as the obvious hysteresis loop, namely that the mesoporous materials with monolayer-multilayer capillary condensation adsorption had obvious capillary condensation in the lower relative pressure range $(\mathrm{p} / \mathrm{p} 0=0.2-0.4)$ due to different nitrogen adsorption and desorption characteristics, thus proving that the materials have uniform columnar pore channels. ${ }^{34}$ Moreover, after the modification by APTES, the functionalized group occupied parts of the pore spaces, and might even block some microscopic pores, thus resulting in a significant reduction in specific surface area, pore size and pore volume of the $\mathrm{MSN}-\mathrm{NH}_{2}{ }^{33}$ 

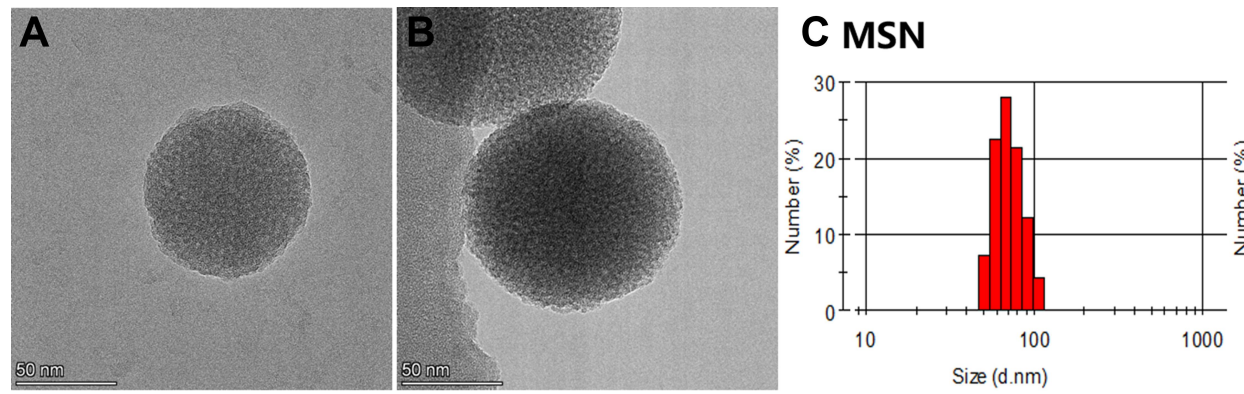

MSN-NH

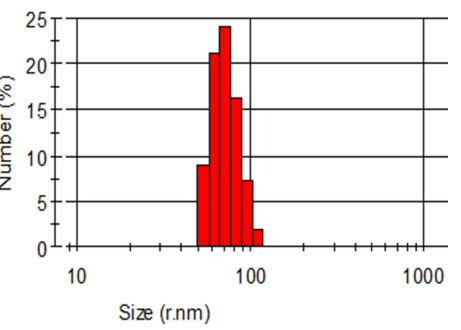

Figure I Morphology characterization of MSN and MSN-NH ${ }_{2}$. (A and B) TEM micrograph of MSN (A) and MSN-NH 2 (B). (C) Size distribution of MSN and MSN-NH 2 .

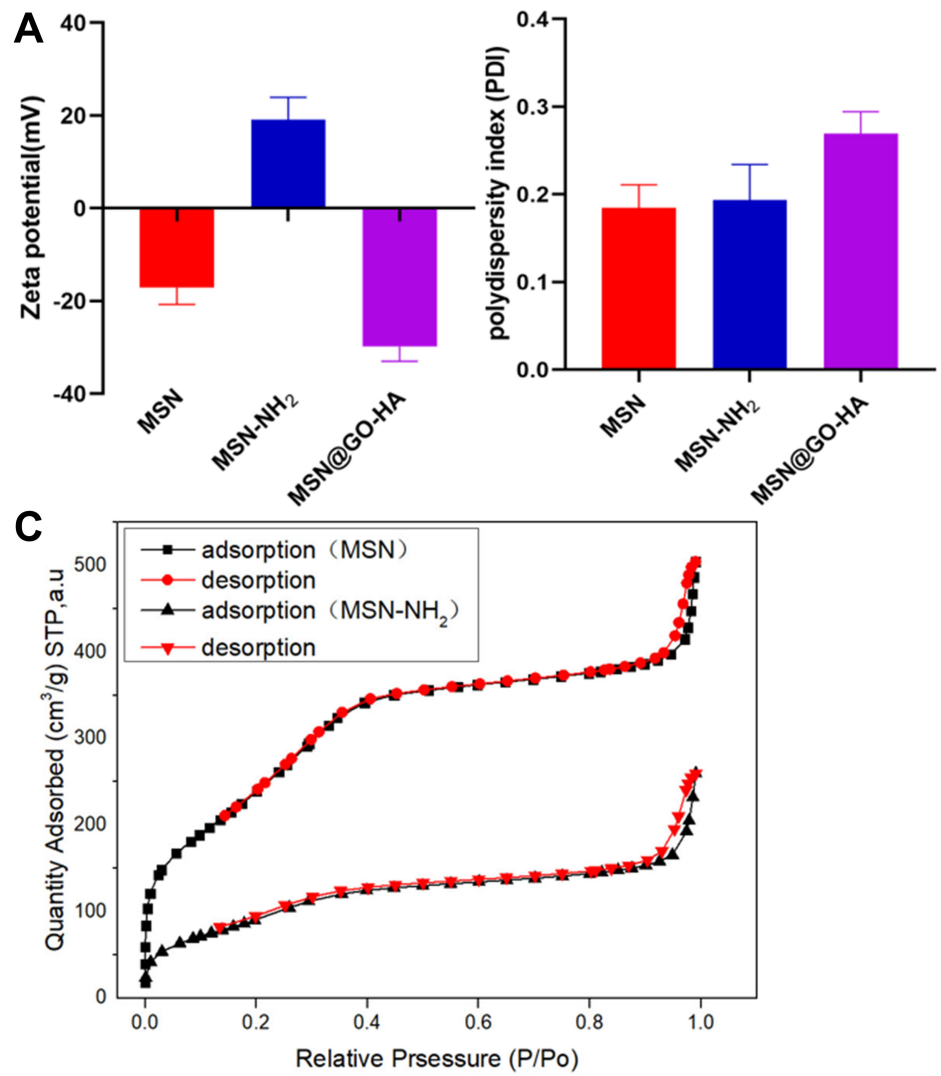

B
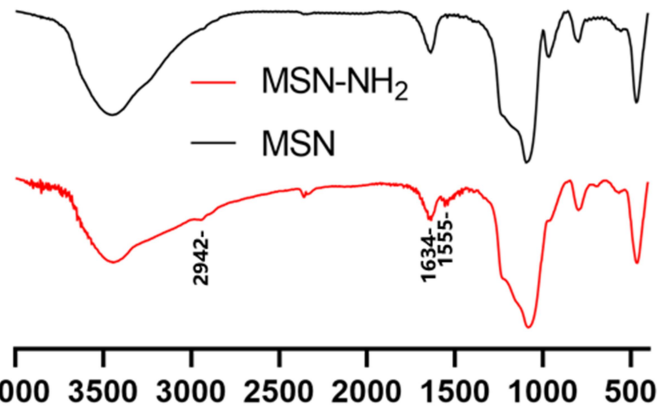

Wavenumber $\left(\mathrm{cm}^{-1}\right)$

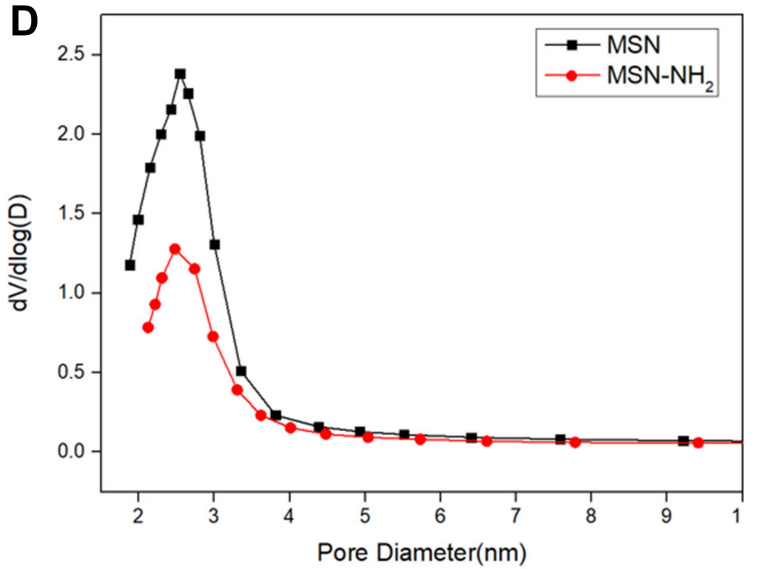

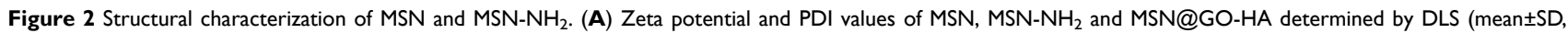
n=3). (B) FTIR spectrum of MSN and MSN-NH . (C and $\mathbf{D})$ Results of nitrogen sorption isotherms tests: (C) Adsorption-desorption isotherms of MSN and MSN-NH ${ }_{2}$; (D) Pore diameter distribution of $\mathrm{MSN}$ and $\mathrm{MSN}-\mathrm{NH}_{2}$.

\section{Characterization of $\mathrm{MSN}_{\mathrm{CA}} @ \mathrm{GO}_{\mathrm{DOX}}$ -HA}

The hydrodynamic size of GO-ns which was formed by the sonication cutting significantly decreased with the prolonged sonication time. The sizes of the final products were $143.4 \pm$ $20.6 \mathrm{~nm}$ after $3 \mathrm{~h}$ sonication (Figure S1, Figure $3 \mathrm{~A}-\mathrm{C}$ ). Then, the hyaluronic acid (HA) linked GO-ns (GO-HA) was synthesized by a two-step reaction, which was characterized by the FTIR spectrum of Figure 3D. The spectrum revealed the presence of $\mathrm{C}=\mathrm{O}\left(1735 \mathrm{~cm}^{-1}\right), \mathrm{C}=\mathrm{C}\left(1627 \mathrm{~cm}^{-1}\right)$ and $\mathrm{C}-\mathrm{O}$ $\left(1092 \mathrm{~cm}^{-1}\right)$ in the structure of GO-ns. The absorption peaks of -CO-NH- groups $\left(3422 \mathrm{~cm}^{-1}, 1647 \mathrm{~cm}^{-1}\right.$ and $\left.1317 \mathrm{~cm}^{-1}\right)$ significantly increased on the surface of GO-ADH after linked with $\mathrm{ADH}$ groups. Moreover, the characteristic absorption peaks of HA $\left(2959 \mathrm{~cm}^{-1}, 1590 \mathrm{~cm}^{-1}\right.$ and $1337 \mathrm{~cm}^{-1}$ ) appeared after the modification with HA, indicating the successful preparation of GO-HA. ${ }^{34}$ Figure 4 shows the morphological characterization results of MSN@GO-HA, MSN@GO and MSM-NH ${ }_{2}$. The TEM image exhibited that the $\mathrm{MSN}-\mathrm{NH}_{2}$ was completely 

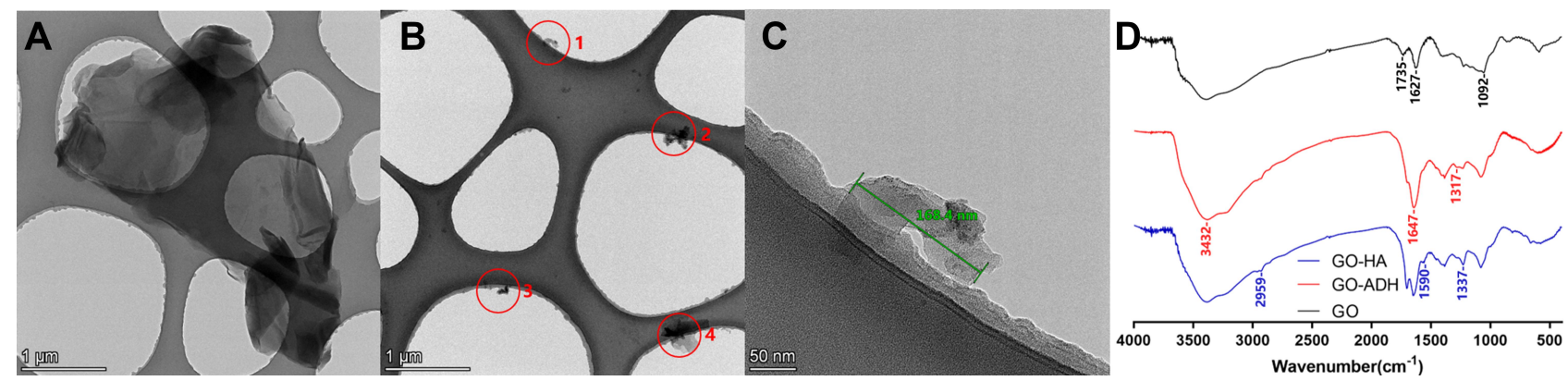

Figure 3 Characterizations of GO-HA. (A) TEM micrograph of GO before sonication. (B) TEM micrograph of GO-ns after sonication. The main GO-ns are circled in red circle in this field of vision. (C) The morphology and size of graphene GO-ns I. (D) FTIR spectrum of GO-ns, GO-ADH and GO-HA.

wrapped by GO-ns or GO-HA to construct the MSN@GO and MSN@GO-HA, respectively. The EDS results revealed that the coverage of GO-ns made the signal intensity of

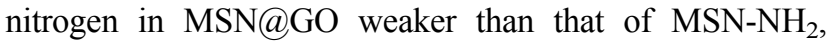
which was then enhanced by the surface modification of HA during the construction of MSN@GO-HA (Figure 4 and Figure S2). The results of XPS analysis of MSN@GOHA also demonstrated that the MSN@GO-HA contained nitrogen, carbon and silicon, and their mass ratio was about 1:4:2 (Figure S3). These results all proved the successful preparation of MSN@GO-HA nanoparticles. In addition, the introduction of HA not only increased the
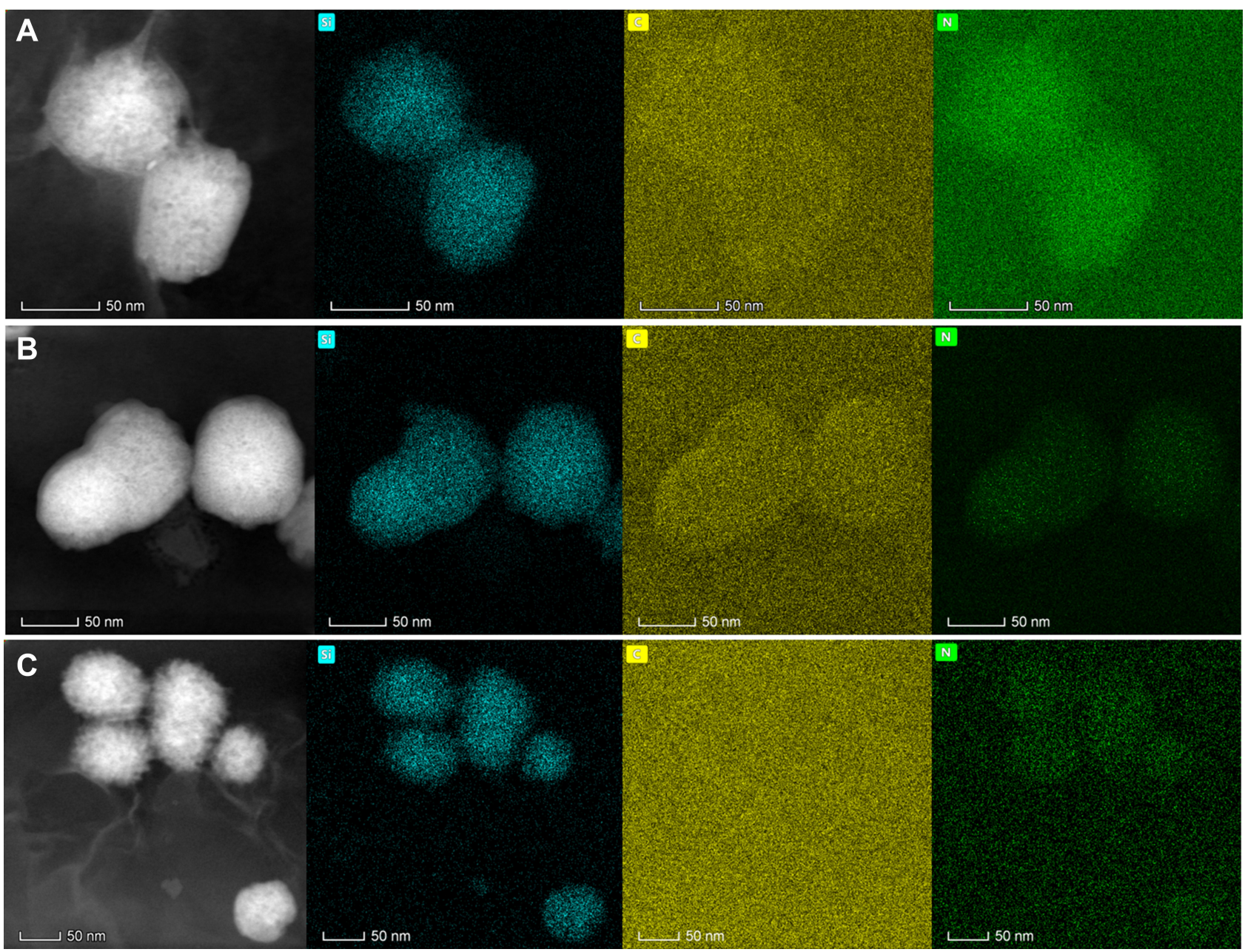

Figure 4 Characterizations of MSN@GO-HA, MSN@GO and MSN-NH 2 . (A) TEM and EDS micrographs of MSN@GO-HA. (B) TEM and EDS micrographs of MSN@GO. (C) TEM and EDS micrographs of $\mathrm{MSN}^{-\mathrm{NH}_{2}}$ (Blue: silicon, yellow: carbon, green: nitrogen). 
Table I The Particle Sizes, PDI, Zeta Potential and Drug-Loading Efficiency of MSN CA $@ G O_{\text {DOX }}-\mathrm{HA}(\mathrm{mean} \pm \mathrm{SD}, \mathrm{n}=3)$

\begin{tabular}{|c|c|c|c|c|c|c|}
\hline \multicolumn{4}{|c|}{ Drug-Loading Efficiency of $\mathrm{MSN}_{\mathrm{CA}} @ \mathrm{GO}_{\mathrm{DOX}}-\mathrm{HA}$} & \multirow[t]{2}{*}{ Particle Sizes (nm) } & \multirow[t]{2}{*}{ PDI } & \multirow[t]{2}{*}{ Zeta Potential (mV) } \\
\hline $\begin{array}{l}\text { EE for CA } \\
\text { (\%) }\end{array}$ & $\begin{array}{l}\text { DL for CA } \\
\text { (\%) }\end{array}$ & $\begin{array}{l}\text { EE for DOX } \\
\text { (\%) }\end{array}$ & $\begin{array}{l}\text { DL for DOX } \\
\text { (\%) }\end{array}$ & & & \\
\hline $84.36 \pm 3.52$ & $20.03 \pm 0.84$ & $64.69 \pm 5.51$ & $4.47 \pm 0.38$ & $115.59 \pm 13.98$ & $0.25 \pm 0.02$ & $-27.53 \pm 4.56$ \\
\hline
\end{tabular}

sizes and PDI of MSN@GO-HA nanoparticles, but also made their Zeta potential become negative charged, which ensured the stability of nanoparticles in the blood circulation (Figure 2A and Figure S4). ${ }^{35}$

During the preparation of $\mathrm{MSN}_{\mathrm{CA}} @ \mathrm{GO}_{\mathrm{DOX}}-\mathrm{HA}$ nanoparticles, MSN and GO-HA were first used to load CA and DOX, respectively, then assembled together to construct the $\mathrm{MSN}_{\mathrm{CA}} @ \mathrm{GO}_{\mathrm{DOX}}-\mathrm{HA}$ through the electrostatic adsorption. In the drug-loading process, the $\mathrm{MSN}-\mathrm{NH}_{2}$ loaded large amounts of CA within a short time due to the openness of their mesoporous structures. However, the loaded CA also diffused back into the solution with the extension of stirring time, resulting in the reduced loading efficiency. Therefore, the stirring time was limited to $12 \mathrm{~h}$ after repeated treatments (Figure S5A). Moreover, DOX was adsorbed on the surface of GO-HA by the $\pi-\pi$ conjugation, which was optimized by adjusting the stirring time $(24 \mathrm{~h})$ and the volume ratio of DOX to GO-HA solution (2:1, v/v) (Figure S5B and $\underline{\mathrm{C}}$ ). During the preparation of $\mathrm{MSN}_{\mathrm{CA}} @ \mathrm{GO}_{\mathrm{DOX}}-\mathrm{HA}$ nanoparticles, the volume ratio of MSN to GO-HA solution was optimized to $1: 1(\mathrm{v} / \mathrm{v})$ through investigating the effects of different volume ratios of $\mathrm{MSN}_{\mathrm{CA}}$ to $\mathrm{GO}_{\mathrm{DOX}}-\mathrm{HA}$ solutions on the drug-loading efficiency and particle size/PDI of nanoparticles (Figure S5D-F), finally obtaining the final composite nanoparticles, whose particle size was about $120 \mathrm{~nm}$ with good loading efficiency for CA and DOX (Table 1). Furthermore, the investigation of the drugloading efficiency demonstrated that the mass ratio of CA to DOX was about 6:1 in per unit weight of $\mathrm{MSN}_{\mathrm{CA}}$ (a) $\mathrm{GO}_{\text {Dox }}-\mathrm{HA}$ nanoparticles.

\section{Serum Stability and in vitro Release}

Figure 5A-E showed the results of serum stability tests. With the extension of the incubation time, the particle size and PDI of $\mathrm{MSN}_{\mathrm{CA}}, \mathrm{MSN}_{\mathrm{CA}} @ \mathrm{GO}_{\mathrm{DOx}}$ and $\mathrm{MSN}_{\mathrm{CA}}$ (a) $\mathrm{GO}_{\mathrm{DOX}}-\mathrm{HA}$ changed in varying degrees. However, there was no severe fluctuation occurred in these data, indicating that these nanoparticles did not undergo structural dissociation, but the continuous adsorption-desorption process between them and the serum protein might be probably occurred, which changed the particle sizes instantaneously, thus leading to the increased heterogeneity of particle sizes, resulting in the gradual increase of PDI (Figure 5A and B). ${ }^{36}$ Moreover, the variation of particle sizes of the three nanoparticles was quite different from each other, namely that the particle size and PDI of $\mathrm{MSN}_{\mathrm{CA}}$ increased the most, then followed the MSN $\mathrm{CA}_{\mathrm{C}} @ \mathrm{GO}_{\mathrm{DOX}}$, and the MSN $\mathrm{CA} @ \mathrm{GO}_{\mathrm{DOX}}-$ HA increased the least (Figure $5 \mathrm{C}$ and D). Furthermore, the escape rate of CA from MSN was greater than $40 \%$ due to the openness of MSN channels, which was much higher than that of $\mathrm{MSN}_{\mathrm{CA}} @ \mathrm{GO}_{\mathrm{DOX}}$ and $\mathrm{MSN}_{\mathrm{CA}}$ (a) $\mathrm{GO}_{\mathrm{DOX}}-\mathrm{HA}$ (both of them were less than $30 \%$ ), indicating the "gatekeeper" function of GO effectively prevented the large-scale release of CA (Figure 5E).

Figure 6 shows the in vitro release results of $\mathrm{CA}$ (Figure 6A) and DOX (Figure 6B). The ultimate cumulative release rates of CA in pH5.0 PBS $(86.4 \%, 48 \mathrm{~h})$ were higher than that in the pH7.4 PBS $(62.3 \%, 48 \mathrm{~h})$ $(P<0.01)$, indicating that the GO cover could prevent CA from freely escaping from MSN channels in a certain degree in pH7.4 PBS. However, the GO-HA fell off from the surface of MSN due to the weakening of electrostatic adsorption between the MSN-NH $\mathrm{N}_{2}$ and GO-HA induced by protons in the acidic environment, thus enabling CA release freely. DOX released rapidly in the acidic environment $(90 \%$ in $48 \mathrm{~h})$, which was much higher than that in the neutral condition $(17.1 \%$ in $48 \mathrm{~h}, P<0.01)$. This might be due to the reduced electronegativity of GO-HA caused by the protonation of the carboxyl groups under the acidic condition, which made the electrostatic repulsion between DOX and GOHA greatly weakened the $\pi-\pi$ conjugation, thus accelerating the release of DOX. ${ }^{37}$

\section{Cytotoxicity}

The cytotoxicity of different CA or DOX preparations on H9c2 and MCF-7 cells was assessed by determining the cell viability at $24 \mathrm{~h}$ post-treatment using the MTT assay. From Figure 7, CA preparations (free $\mathrm{CA}$ and $\mathrm{MSN}_{\mathrm{CA}}$ ) did not 

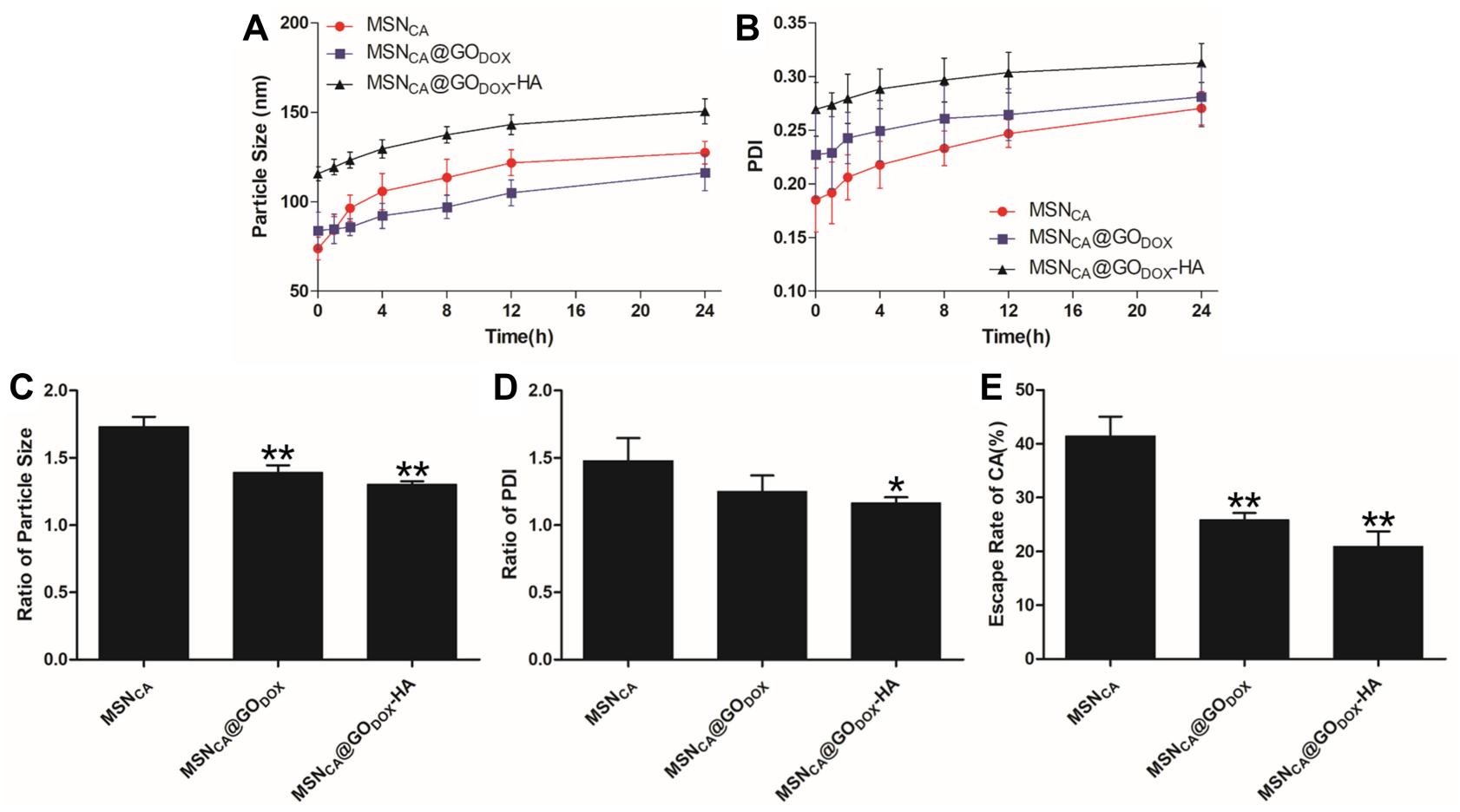

Figure 5 Serum stability studies. (A and B) Effect of the fetal bovine serum (FBS) solution on the particle size (A) and PDI (B) of MSN $\mathrm{CA}_{\mathrm{A}}, \mathrm{MSN}_{\mathrm{CA}} @ \mathrm{GOO}_{\mathrm{DOX}}$, and MSN $@ G_{\text {Dox }}-\mathrm{HA}$ (mean $\pm S D, n=3$ ). (C and $\left.\mathbf{D}\right)$ The ratio of the particle size $(\mathbf{C})$ and PDI (D) of $\mathrm{MSN}_{\mathrm{CA}}, \mathrm{MSN}_{\mathrm{CA}} @ G \mathrm{GO}_{\mathrm{DOX}}$, and $\mathrm{MSN}_{\mathrm{CA}} @ \mathrm{GO}_{\mathrm{DOX}}-\mathrm{HA}$ after incubated in FBS solution for $24 \mathrm{~h}$ and before incubation (mean $\pm S D, n=3$ ). $* * P<0.01$, $* P<0.05$ : significantly different from $M S N_{C A}$. (E) Escape rate of CA from different preparations during the incubation (mean $\pm \mathrm{SD}, \mathrm{n}=3$ ). $* * \mathrm{P}<0.01$ : significantly different from $\mathrm{MSN}_{\mathrm{CA}}$.
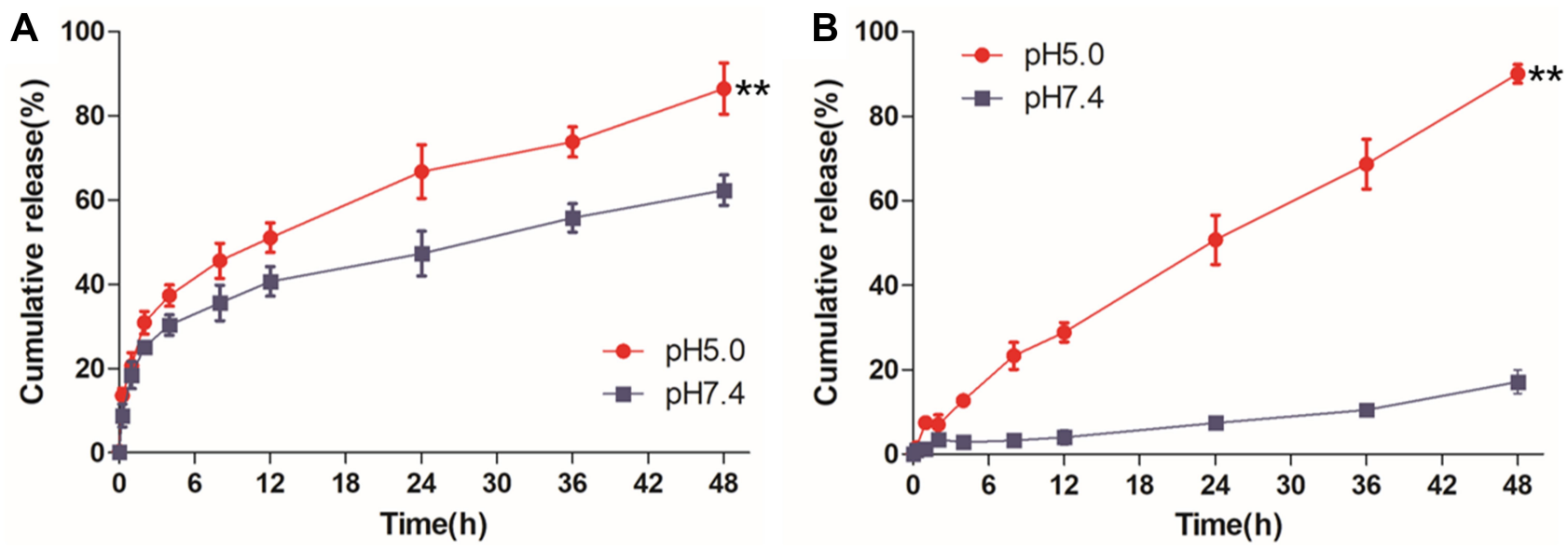

Figure 6 In vitro release study of $C A(A)$ and $D O X(B)$ from $M S N_{C A} @ G O_{D O X}-H A$ in $P B S$ solutions with different $p H$ values (mean $\pm S D$, $n=3$ ). **P<0.0I: significantly different from that in $\mathrm{pH} 7.4$ release media.

exert any cytotoxicity on $\mathrm{H} 9 \mathrm{c} 2$ cells. The co-loaded preparations $\left(\mathrm{MSN}_{\mathrm{CA}} @ \mathrm{GO}_{\mathrm{DOX}}\right.$ and $\left.\mathrm{MSN}_{\mathrm{CA}} @ \mathrm{GO}_{\mathrm{DOX}}-\mathrm{HA}\right)$ inhibited the viability of $\mathrm{H} 9 \mathrm{c} 2$ cells to a certain extent, but their inhibitory effect was inferior to that of DOX preparations ( $\mathrm{GO}_{\mathrm{DOX}}$ or free DOX). Furthermore, the co-loaded preparations were more toxic to MCF-7 cells than $\mathrm{CA}$ or DOX within the set concentration range, and the modification with HA further enhanced their cytotoxicity. Table 2 shows the $\mathrm{IC}_{50}$ values of different $\mathrm{CA}$ and $\mathrm{DOX}$ preparations on H9c2 or MCF-7 cells. For different CA preparations, the $\mathrm{IC}_{50}$ values of $\mathrm{H} 9 \mathrm{c} 2$ cells after treated with $\mathrm{CA}$ and $\mathrm{MSN}_{\mathrm{CA}}$ were all greater than $10,000 \mu \mathrm{g} / \mathrm{mL}$, while the two co-loaded preparations $\left(\mathrm{MSN}_{\mathrm{CA}} @ \mathrm{GO}_{\mathrm{DOX}}\right.$ and $\left.\mathrm{MSN}_{\mathrm{CA}} @ \mathrm{GO}_{\mathrm{DOX}}-\mathrm{HA}\right)$ exerted different toxicities on $\mathrm{H} 9 \mathrm{c} 2$ cells, which ranged from 200 to $250 \mu \mathrm{g} / \mathrm{mL}$. However, the $\mathrm{IC}_{50}$ values of MCF-7 cells after treated with $\mathrm{CA}$ or $\mathrm{MSN}_{\mathrm{CA}}$ were all less than $300 \mu \mathrm{g} /$ 

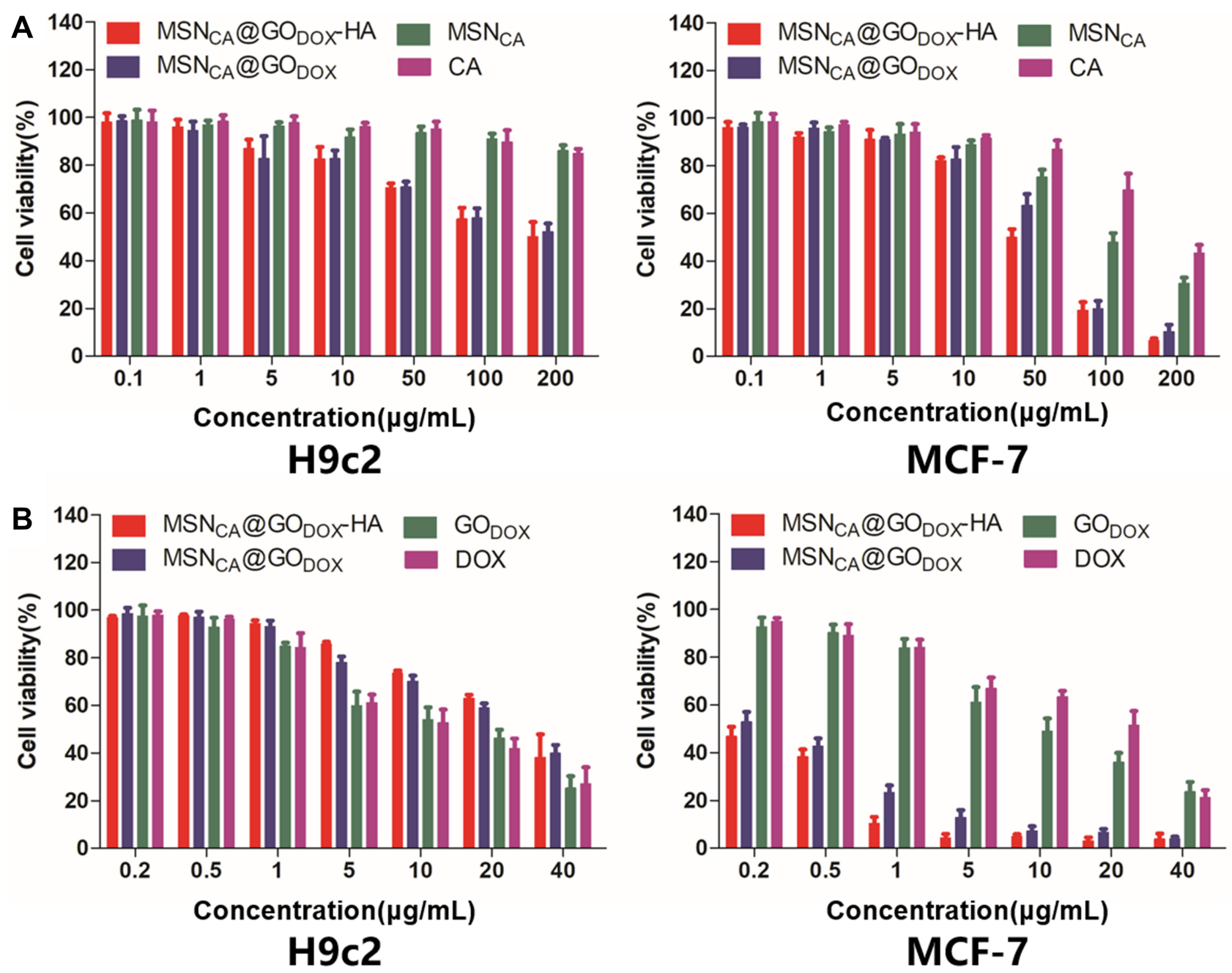

Figure 7 In vitro cytotoxicity study. (A) Cytotoxicity of different CA preparations on H9c2 and MCF-7 cells. (B) Cytotoxicity of different DOX preparations on H9c2 and MCF-7 cells (mean \pm SD, $n=3$ ).

$\mathrm{mL}$, and the $\mathrm{IC}_{50}$ values decreased more obviously after the treatment with $\mathrm{MSN}_{\mathrm{CA}} @ \mathrm{GO}_{\mathrm{DOX}}(41.79 \mu \mathrm{g} / \mathrm{mL})$ or $\mathrm{MSN}_{\mathrm{CA}}$ @ $\mathrm{GO}_{\text {Dox }}-\mathrm{HA}(32.32 \mu \mathrm{g} / \mathrm{mL})$, respectively. For different DOX preparations, the $\mathrm{IC}_{50}$ values of $\mathrm{H} 9 \mathrm{c} 2$ cells after treated with $\mathrm{GO}_{\mathrm{DOX}}, \mathrm{MSN}_{\mathrm{CA}} @ \mathrm{GO}_{\mathrm{DOX}}$ and $\mathrm{MSN}_{\mathrm{CA}} @ \mathrm{GO}_{\mathrm{DOX}}-\mathrm{HA}$ were $0.90,0.39$ and 0.31 times of the cells treated with free DOX, respectively. The $\mathrm{IC}_{50}$ values of MCF-7 cells after treated with $\mathrm{GO}_{\mathrm{DOX}}, \mathrm{MSN}_{\mathrm{CA}} @ \mathrm{GO}_{\mathrm{DOX}}$ and $\mathrm{MSN}_{\mathrm{CA}}$ @ $\mathrm{GO}_{\mathrm{DOX}}-\mathrm{HA}$ were $1.58,63.27$ and 99.43 times of the cells treated with free DOX, respectively.

Table $2 \mathrm{IC}_{50}$ Values of Different CA and DOX Preparations on H9c2 or MCF-7 Cells (mean \pm SD, n=3)

\begin{tabular}{|c|c|c|c|c|c|}
\hline \multirow[t]{2}{*}{ Formulations } & \multicolumn{2}{|c|}{$I C_{50}$ of $C A(\mu \mathrm{g} / \mathrm{mL})$} & \multirow[t]{2}{*}{ Formulations } & \multicolumn{2}{|c|}{$I C_{50}$ of DOX $(\mu \mathrm{g} / \mathrm{mL})$} \\
\hline & H9c2 & MCF-7 & & H9c2 & MCF-7 \\
\hline CA & $>10,000$ & $276.08 \pm 75.58$ & DOX & $|2.35 \pm 1.5|$ & $13.92 \pm 1.38$ \\
\hline $\mathrm{MSN}_{\mathrm{CA}}$ & $>10,000$ & $108.93 \pm 14.04$ & $\mathrm{GO}_{\mathrm{DOX}}$ & $13.68 \pm 0.96$ & $8.98 \pm 1.82$ \\
\hline $\mathrm{MSN}_{\mathrm{CA}} @ \mathrm{GO}_{\mathrm{DOX}}$ & $236.35 \pm 32.69 * *$ & $41.79 \pm 0.70^{\#}$ & $\mathrm{MSN}_{\mathrm{CA}} @ G \mathrm{GOOX}_{\mathrm{DOX}}$ & $31.23 \pm 5.12^{\Delta \Delta}$ & $0.22 \pm 0.020^{\dagger \dagger}$ \\
\hline $\mathrm{MSN}_{\mathrm{CA}} @ \mathrm{GO}_{\mathrm{DOX}}-\mathrm{HA}$ & $215.99 \pm 38.65 * *$ & $32.32 \pm 0.22^{\# \#}$ & $\mathrm{MSN}_{\mathrm{CA}} @ \mathrm{GO}_{\mathrm{DOX}}-\mathrm{HA}$ & $40.34 \pm 11.49^{\Delta \Delta}$ & $0.14 \pm 0.030^{\dagger \dagger}$ \\
\hline
\end{tabular}

Notes: $* * P<0.0$, significantly different from the $\mathrm{H} 9 \mathrm{c} 2$ cells treated with free $\mathrm{CA}$; ${ }^{\#} \mathrm{P}<0.0 \mathrm{I},{ }^{\#} P<0.05$, significantly different from the MCF-7 cells treated with free CA; ${ }^{\triangle} P$ P 0.0 I, significantly different from the H9c2 cells treated with free DOX; ${ }^{\dagger \dagger} P<0.01$, significantly different from the MCF-7 cells treated with free DOX. 


\section{Tumor Cells Uptake}

The tumor cell uptake experiment was carried out to investigate whether the significant toxicity of $\mathrm{MSN}_{\mathrm{CA}} @ \mathrm{GO}_{\mathrm{DOX}}$ HA on MCF-7 cells was related to the increase of cell uptake. DOX was employed as the fluorescent probe to investigate the cellular internalization of $\mathrm{MSN}_{\mathrm{CA}} @ \mathrm{GO}_{\mathrm{DOX}}$ HA since it emits red fluorescence under a certain wavelength of excitation light. ${ }^{38}$ Figure $8 \mathrm{~A}$ shows the results of qualitatively uptake observation. The cell nuclei were stained in blue by DAPI, and different intensities of DOX fluorescence were presented in the cytoplasm after incubation for $4 \mathrm{~h}$. Specifically, different DOX-loaded carriers exhibited obvious higher fluorescence intensity than free DOX, and the fluorescence intensity augmented from the $\mathrm{GO}_{\text {DOX }}$ to the MSN@ $\mathrm{GO}_{\text {DOX }}-\mathrm{HA}$. The flow cytometry results confirmed that the uptake of $\mathrm{MSN} @ \mathrm{GO}_{\mathrm{DOx}}-\mathrm{HA}$ by MCF-7 cells was the highest compared with other preparations, then followed the $\mathrm{MSN} @ \mathrm{GO}_{\mathrm{DOx}}$, which was consistent with the results of qualitative uptake experiments (Figure 8B and Figure S6). Moreover, the competitive inhibition test indicated that the addition of free HA did not show any effects in the uptake of free DOX, $\mathrm{GO}_{\text {DOx }}$ or MSN@GO $G_{\text {DOx }}$. However, the uptake of MSN@GO $\mathrm{GOX}^{-}$ HA decreased significantly, indicating the obvious inhibitory effect, which was more significant as the amount of HA increased (Figure 9). The above results suggested that the $\mathrm{MSN}_{\mathrm{CA}} @ \mathrm{GO}_{\mathrm{DOX}}-\mathrm{HA}$ could be actively transported into the tumor cell by the recognition of HA through CD44 receptor which was highly expressed on the surface of tumor cells, thus increasing the internalization of $\mathrm{CA}$ and DOX.

\section{Detection of Intracellular ROS} Generation and Mitochondrial Function

The ROS detection tests employed the DCFH-DA as the ROS marker to evaluate the ROS generation in MCF-7 cells induced by different CA or DOX preparations, which is hydrolyzed to DCF and generate highly green fluorescent signal once reacted with the intracellular ROS. ${ }^{39}$ From Figure $10 \mathrm{~A}$ and $\mathrm{B}$, the intracellular ROS levels increased significantly after incubated by different CA preparations. The ROS levels of different experimental groups were 3.50 $\left(\mathrm{MSN}_{\mathrm{CA}} @ \mathrm{GO}_{\mathrm{DOx}}-\mathrm{HA}\right), 3.26$ (MSN $\left._{\mathrm{CA}} @ \mathrm{GO}_{\mathrm{DOx}}\right), 2.08$ $\left(\mathrm{MSN}_{\mathrm{CA}}\right)$, and 2.20 (CA) times of the blank control group, respectively. Moreover, after incubated by different DOX preparations, the ROS levels of different experimental groups were $3.79\left(\mathrm{MSN}_{\mathrm{CA}} @ \mathrm{GO}_{\mathrm{DOX}}-\mathrm{HA}\right), 3.56\left(\mathrm{MSN}_{\mathrm{CA}}\right.$ $\left.@ \mathrm{GO}_{\mathrm{DOX}}\right), 1.65\left(\mathrm{GO}_{\mathrm{DOX}}\right)$, and 1.54 (DOX) times of the blank control group, respectively.

The MMP detection of MCF-7 cells after treated with different CA or DOX preparations was detected by JC-1, which transforms reversibly from the monomer (green fluorescence) into the aggregate form (red fluorescence) once bound with high MP. Therefore, the mitochondrial depolarization is indicated by the decrease in the ratio of red/green fluorescence intensity. ${ }^{40}$ From Figure $10 \mathrm{C}$ and D, the red/green ratio of different CA experimental groups was 0.23 (MSN $\left.{ }_{\mathrm{CA}} @ \mathrm{GO}_{\mathrm{DOX}}-\mathrm{HA}\right), 0.36$ ( $\left.\mathrm{MSN}_{\mathrm{CA}} @ \mathrm{GO}_{\mathrm{DOX}}\right)$, $0.44\left(\mathrm{MSN}_{\mathrm{CA}}\right)$, and $0.47(\mathrm{CA})$ times of the blank control group, respectively. Meanwhile, the red/green ratio of different DOX preparations was $0.10\left(\mathrm{MSN}_{\mathrm{CA}} @ \mathrm{GO}_{\mathrm{DOX}}-\mathrm{HA}\right)$, $0.22\left(\mathrm{MSN}_{\mathrm{CA}} @ \mathrm{GO}_{\mathrm{DOX}}\right), 0.58$ (GO $\left.\mathrm{GOX}\right)$, and 0.62 (DOX) times of the blank control group.
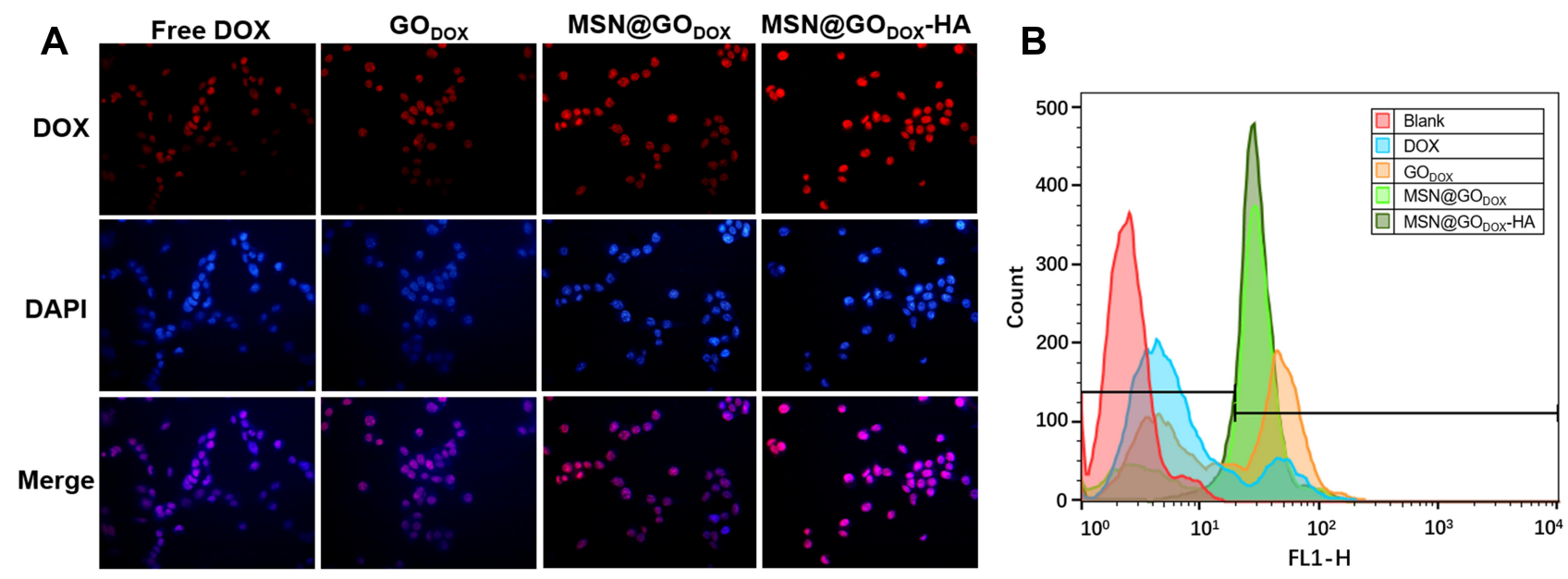

Figure 8 Investigation of MCF-7 cell uptake. Qualitatively (A) and quantitatively (B) analyses of MCF-7 cells treated with different DOX-loaded preparations for 4h, detected by the inverted fluorescence microscope and flow cytometry, respectively. 


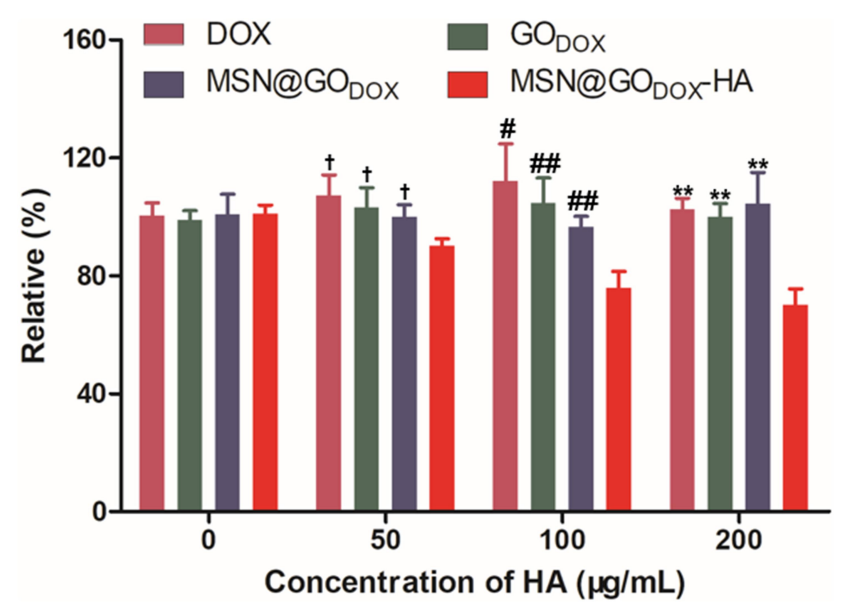

Figure 9 Results of the competitive cellular uptake in MCF-7 cells. Relative uptake efficiency of free DOX, GO DOX, MSN@GO without HA for $4 \mathrm{~h}$ in MCF-7 cells. ${ }^{*} * \mathrm{P}<0.0 \mathrm{I}$ : significantly different from the MSN@GO ${ }_{\text {DOX }}-\mathrm{HA}$ group when the HA concentration was $200 \mu \mathrm{g} / \mathrm{mL}$. ${ }^{\#} P<0.01$, ${ }^{\#} P<0.05$ : significantly different from the MSN@GO ${ }_{D O x}-H A g r o u p$ when the HA concentration was $100 \mu \mathrm{g} / \mathrm{mL}$. ${ }^{\dagger} P<0.05$ : significantly different from the MSN@GO ${ }_{\text {DOX }}-\mathrm{HA}$ group when the HA concentration was $50 \mu \mathrm{g} / \mathrm{mL}$.
Furthermore, as ATP is generated during the biological oxidation process in the mitochondrial inner membrane, whose production is closely related to the mitochondrial function. Therefore, the ATP content was also investigated using the same batch of cell as those used for the MMP detection. From Figure 10E and F, all CA or DOX preparations induced the decline of ATP level in MCF-7 cells. Moreover, compared with other control groups, $\mathrm{MSN}_{\mathrm{CA}} @ \mathrm{GO}_{\mathrm{DOX}}-\mathrm{HA}$ showed a more significant effect on the changes in ATP content, then followed the MSN $\mathrm{CA}_{\mathrm{CA}} @ \mathrm{GO}_{\mathrm{DOx}}$. Furthermore, like the results of MMP test, $\mathrm{CA}$ (free $\mathrm{CA}$ and $\mathrm{MSN}_{\mathrm{CA}}$ ) exhibited more significant influence on the ATP content of MCF-7 cells compared with DOX alone (free DOX and $\mathrm{GO}_{\mathrm{DOX}}$ ) at the set concentration. The above results indicated that CA showed greater effects on the mitochondrial function compared with DOX at the set concentration, namely that CA induced ROS amplification by damaging mitochondrial electron transport
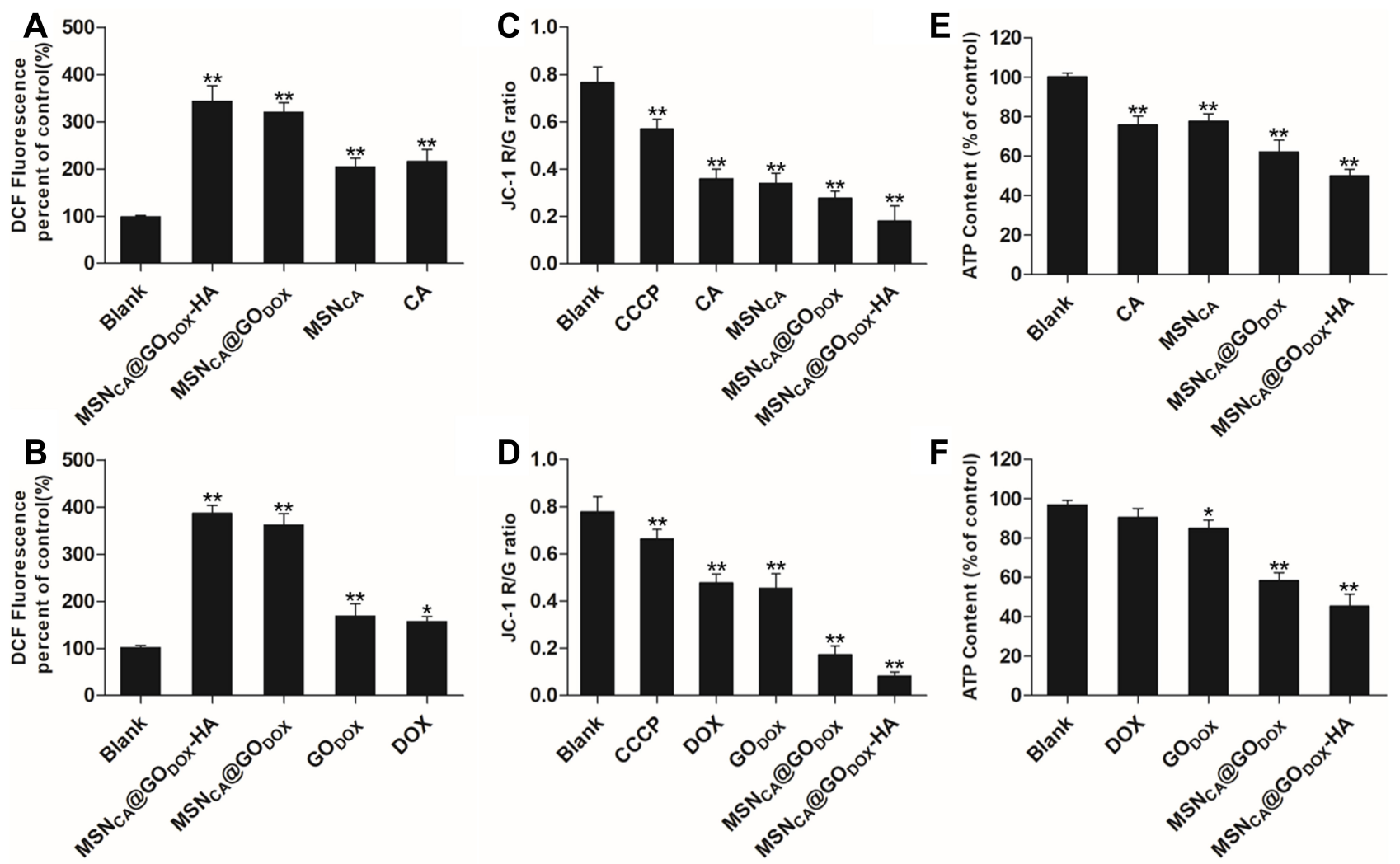

Figure 10 Detection of intracellular ROS level and mitochondrial function of MCF-7 cells. (A and B) Changes in ROS level after incubation with different CA (A) or DOX (B) preparations (mean $\pm S D, n=3$ ), the $Y$-axis was expressed as the ratio of the $D C F$ fluorescence intensity of each group to that of the blank group. $* * P<0.0 \mathrm{I}$, $* P<0.05$ : significantly different from the blank group. (C and D) The effects of different CA (C) or DOX (D) preparations on mitochondrial membrane potential of MCF-7 cells (mean $\pm S D, n=3)$. The mitochondrial electron transport chain inhibitor carbonyl cyanide 3-chlorophenylhydrazone $(C C C P)$ was set as the positive control. $* * P<0.0 \mathrm{I}$ : significantly different from the blank group. (E and $\mathbf{F}$ ) Changes in the intracellular ATP level of MCF-7 cells after incubated with different CA (E) or DOX (F) preparations (mean \pm SD, $\mathrm{n}=3)$. $* *<<0.0 \mathrm{I}, * P<0.05$ : significantly different from the blank group. In the above experiments, the concentration of each preparation was fixed at $200 \mu g / \mathrm{mL}$ or $40 \mu g / \mathrm{mL}$ normalized by the concentration of free CA or DOX. 
chain, and affected mitochondrial membrane permeability and ATP synthesis. Moreover, the combination of CA and DOX exerted a greater impact on the above processes.

\section{Detection of Caspase-3 and Caspase-9 Activities}

In this work, in order to further explore the affection of coloaded preparations on the apoptosis process through affecting the mitochondrial function, two key proteases, Caspase-3 and Caspase- 9 were detected, respectively, which were the major participants in the intrinsic apoptosis pathway. As shown in Figure 11, CA (free CA and $\mathrm{MSN}_{\mathrm{CA}}$ ) increased Caspase-3/Caspase- 9 by a greater extent compared with DOX (free DOX and $\mathrm{GO}_{\mathrm{DOX}}$ ) at the set concentration, indicating that CA could directly induce the opening of intrinsic apoptosis pathway by affecting the mitochondrial function. Meanwhile, results also showed that the level of Caspase-3 and Caspase-9 significantly increased upon the application of the co-loaded preparations $\left(\mathrm{MSN}_{\mathrm{CA}} @ \mathrm{GO}_{\mathrm{DOX}}-\mathrm{HA}\right.$ and $\left.\mathrm{MSN}_{\mathrm{CA}} @ \mathrm{GO}_{\mathrm{DOX}}\right)$ in comparison with single CA or DOX group. Moreover, the introduction of HA limitedly enhanced the function of $\mathrm{MSN}_{\mathrm{CA}} @ \mathrm{GO}_{\mathrm{DOX}}-\mathrm{HA}$ nanoparticles by enhancing the cellular internalization process of co-loaded nanoparticles. The above results revealed that CA could effectively promote the opening of the intrinsic apoptosis pathway through affecting the mitochondrial function, and the precise co-delivery of CA and DOX by co-loaded preparations further promoted this process.

\section{Discussion}

Cinnamaldehyde (CA) is commonly used in the food and beverage production as a flavoring agent. Recent studies showed that CA exerted potential medicinal properties due to its active michael acceptor pharmacophore, namely inducing apoptosis by the selective enhancement of oxidative stress in tumor cells.
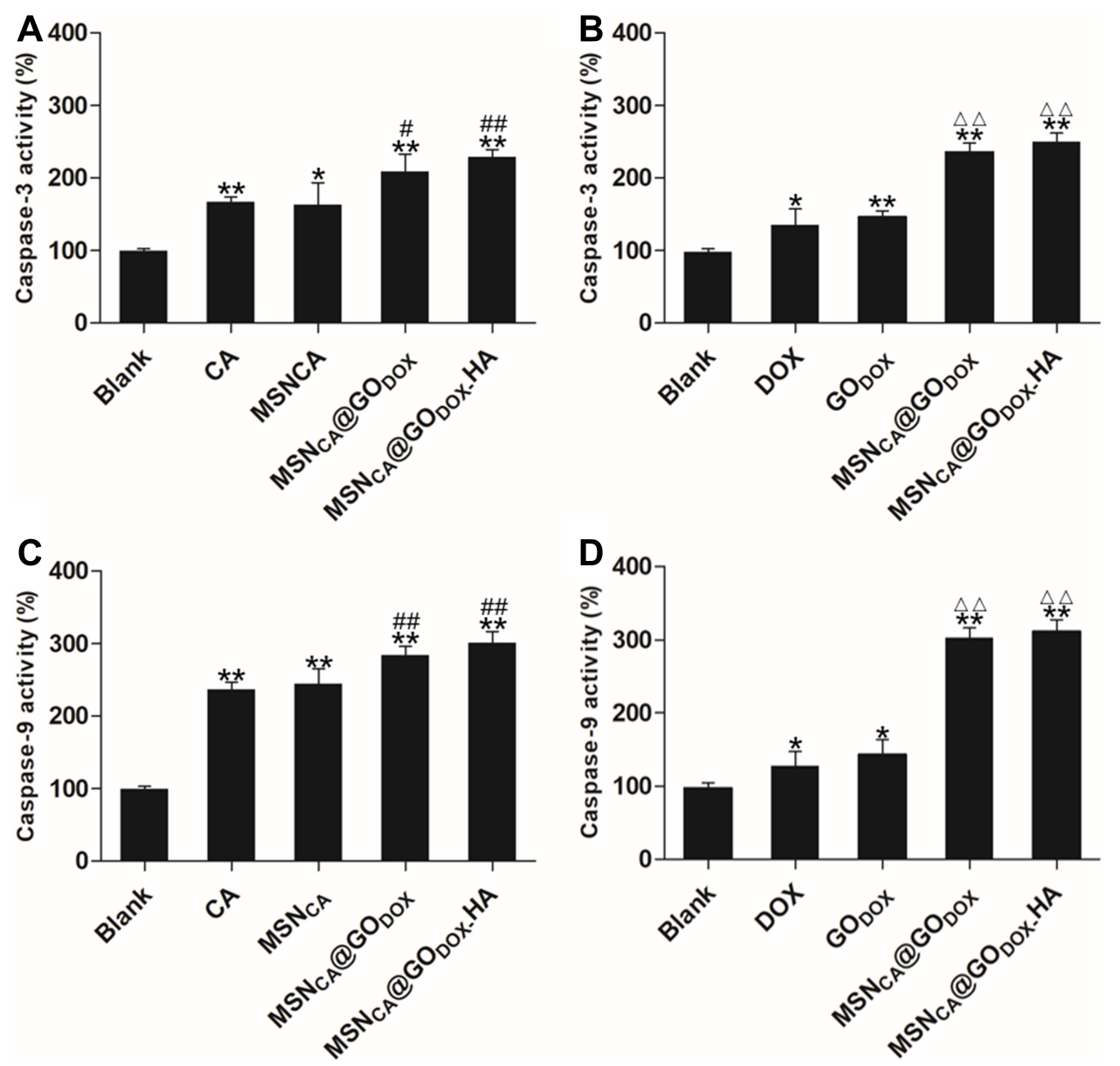

Figure I I Effect of different CA and DOX preparations on Caspase-3 (A and B) and Caspase-9 (C and D) activities of MCF-7 cells (mean \pm SD, $n=3$ ). The concentration of each preparation was fixed at $40 \mu \mathrm{g} / \mathrm{mL}$ or $5 \mu \mathrm{g} / \mathrm{mL}$ normalized by the concentration of free $C A$ or $D O X$. $* * P<0.0 \mathrm{I}$, $* P<0.05$ : significantly different from the blank group. ${ }^{\#} P<0.0$ I, ${ }^{\#} P<0.05$ : significantly different from the $C A$ group. ${ }^{\Delta \triangle} P<0.01$ : significantly different from the DOX group. 
Unfortunately, the anti-tumor research of CA is still far from clinical application due to its short half-life in vivo caused by the easily oxidized aldehyde group. DOX is an effective and widely used chemotherapeutic agent, which has been employed to treat many solid tumors and malignant hematologic disease. ${ }^{41}$ However, cardiotoxicity, which is characterized by a dose-dependent decline in cardiac function with prolonged exposure, greatly restricts the clinical use of DOX. ${ }^{42}$ Therefore, the MSN@GO-HA composite nanoparticles were constructed to achieve the simultaneous loading, collaborative therapy and reduction of application defects of CA and DOX. The mesoporous structures give MSN high loading capacity, which enable CA to be diffused into their channels freely to achieve high loading efficiency. GO is a two-dimensional hexagonal carbon nanomaterial composed of carbon atoms with $\mathrm{SP}^{2}$ hybrid orbitals. The unique structure allows GO to adsorb DOX (containing the aromatic ring structure) through the $\pi-\pi$ conjugated effect. Moreover, the opposite surface charges of MSN$\mathrm{NH}_{2}$ and GO-HA enabled them to combined together through the electrostatic adsorption, which also led to the different performance in the serum stability test of these carriers (Figure 5). The positively charged $\mathrm{MSN}_{\mathrm{CA}}$ quickly adsorb serum protein to increase its particle size significantly. The $\mathrm{MSN}_{\mathrm{CA}} @ \mathrm{GO}_{\mathrm{DOx}}$ was closed to the electric neutrality, thus making it adsorb less serum protein than $\mathrm{MSN}_{\mathrm{CA}}$. Due to the surface modification with negatively charged HA, the $\mathrm{MSN}_{\mathrm{CA}} @ \mathrm{GO}_{\mathrm{DOx}}-\mathrm{HA}$ showed a certain electrostatic repulsion to the negatively charged serum proteins, finally resulting in the minimal increase of particle sizes and maintained the structural integrity in the blood circulation. Therefore, the release of $\mathrm{CA}$ from $\mathrm{MSN}_{\mathrm{CA}} @ \mathrm{GO}_{\mathrm{DOx}}-\mathrm{HA}$ was also controlled to a certain extent in $\mathrm{pH} 7.4$ PBS simulating blood circulation, in order to avoid the oxidative failure of $\mathrm{CA}$ caused by premature exposure before entering the tumor cells. While in the pH5.0 PBS simulating the intracellular environment of tumor cells, the existence of protons weakened the electrostatic adsorption and made GO-HA fell off from the MSN surface, thus accelerating the release of $\mathrm{CA}$. Moreover, the conjugation between GO and DOX was also weakened due to the reduced electronegativity of GO-HA induced by protons, thus leading to the obvious $\mathrm{pH}$-responsive release of DOX (Figure 6). These results indicated that the $\mathrm{MSN}_{\mathrm{CA}} @ \mathrm{GO}_{\mathrm{DOX}}-\mathrm{HA}$ nanoparticles could keep stable in the blood circulation, while achieved the pH- responsive release of $\mathrm{CA}$ and DOX in the acidic lysosome environment after the endocytosis of tumor cells, thus improving the intracellular drug accumulation ${ }^{43}$

In the cell experiments, since $\mathrm{MSN}_{\mathrm{CA}} @ \mathrm{GO}_{\mathrm{DOX}}-\mathrm{HA}$ and $\mathrm{MSN}_{\mathrm{CA}} @ \mathrm{GO}_{\mathrm{DOx}}$ were the co-loaded preparations of $\mathrm{CA}$ and DOX, the two therapeutic drugs were always applied to the cell culture medium simultaneously at a certain ratio when investigating the effect of co-loaded preparations on cells, thereby achieving the purpose of cotreatment. The results of cytotoxicity study demonstrated that when the CA concentration was employed as the standard to calibrate the concentration of the composite nanoparticles, significant toxicity could be observed in MCF-7 cells, while the toxicity to $\mathrm{H} 9 \mathrm{c} 2$ cells was limited (the viability of $\mathrm{H} 9 \mathrm{c} 2$ cells was higher than $50 \%$ when the CA concentration was $200 \mu \mathrm{g} / \mathrm{mL}$ ). However, when the DOX concentration was used as the standard to calibrate the concentration of the composite nanoparticles, the composite nanoparticles not only significantly killed MCF-7 cells, but also caused a certain toxicity to $\mathrm{H} 9 \mathrm{c} 2$ cells (the viability of $\mathrm{H} 9 \mathrm{c} 2$ cells was close to $50 \%$ when the DOX concentration was $40 \mu \mathrm{g} / \mathrm{mL}$ ). Since CA and DOX were simultaneously loaded in MSN@GO-HA nanoparticles in a certain proportion (the mass ratio is about $6: 1, \mathrm{~m}_{\mathrm{CA}}$ : $\left.\mathrm{m}_{\mathrm{DOX}}\right)$, the appropriate concentration of the composite nanoparticles should be calibrated according to one of their concentrations. When the CA concentration was $200 \mu \mathrm{g} / \mathrm{mL}$, the composite nanoparticles achieved high killing effect to tumor cells and low toxicity to normal cells, and the DOX concentration was about $33 \mu \mathrm{g} / \mathrm{mL}$ in the same nanoparticles. However, the DOX concentration $(40 \mu \mathrm{g} / \mathrm{mL})$ used as the concentration setting standard of $\mathrm{MSN}_{\mathrm{CA}} @ \mathrm{GO}_{\mathrm{DOx}}-\mathrm{HA}$ nanoparticles made the concentration of the composite nanoparticles varied more widely (eg the concentration of $\mathrm{CA}$ was close to $250 \mu \mathrm{g} / \mathrm{mL}$ in the same nanoparticles), which produced a certain toxicity to normal cells, since both concentrations of DOX and CA in the composite nanoparticles were greater than that in the composite nanoparticles calibrated by CA $(200 \mu \mathrm{g} / \mathrm{mL})$. The above results revealed that the purpose of killing breast cancer cells and reducing toxic side-effects might be achieved by reasonably adjusting the concentration of the composite nanoparticles. Moreover, CA (free CA and $\mathrm{MSN}_{\mathrm{CA}}$ ) exerted almost no toxicity on $\mathrm{H} 9 \mathrm{c} 2$ cells, and the co-loaded preparations $\left(\mathrm{MSN}_{\mathrm{CA}} @ \mathrm{GO}_{\mathrm{DOX}}-\mathrm{HA}\right.$ and $\left.\mathrm{MSN}_{\mathrm{CA}} @ \mathrm{GO}_{\mathrm{DOX}}\right)$ induced lower cytotoxicity than DOX alone (free DOX and $\left.\mathrm{GO}_{\mathrm{DOX}}\right)(P<0.01)$ (Figure 7 and Table 2), indicating the selective mechanism of CA- 
induced apoptosis. The tumor cell uptake studies also revealed that the affinity of HA to the highly expressed CD44 receptors on the surface of tumor cells enhanced the uptake of $\mathrm{MSN}_{\mathrm{CA}} @ \mathrm{GO}_{\mathrm{DOX}}-\mathrm{HA}$ and the internalization of $\mathrm{CA}$ and DOX, thus contributing their cytotoxicity (Figures 8, 9 and $\underline{\mathrm{S} 6}$ ).

Due to the high basal ROS level in tumor cells, CA can selectively increase the ROS signal by destroying the function of the mitochondrial respiratory chain and increasing the electron leakage. ${ }^{44}$ The ROS level detection revealed that $\mathrm{CA}$ caused a more pronounced increase in ROS levels than DOX at the set concentration (Figure 10A and B). Moreover, the co-loaded nanoparticles exhibited the superior ROS induction than CA alone, which might be attributed to the good preservation of $\mathrm{CA}$ in their structure and the active targeting. The results of MMP detection showed a certain corresponding relationship with the measurement of ROS level, that was, the high ROS level corresponded to the low membrane potential, and vice versa (Figure 10C and D). MMP is the electrochemical gradient formed during the operation of the mitochondrial respiratory chain. ${ }^{45,46}$ The decreased MMP was mainly attributed to the effect of $\mathrm{CA}$ on the mitochondrial respiratory chain. CA also affects the content of ATP, which is synthesized by the ATP synthase on the mitochondrial inner membrane via the MMP. Since ATP provides energy for the $\mathrm{ABC}$ transporters which are highly expressed on the surface of tumor cells, ${ }^{47}$ the inhibition of CA on the synthesis of ATP may further inhibits the efflux function of these proteins, thereby enhancing the effects of DOX indirectly by increasing its intracellular accumulation, which have been verified by some existing studies, and we will further confirm this conclusion in DOX resistant tumor cells. ${ }^{24,48}$ DOX not only achieves the anti-tumor effect by interfering with the transcription process of DNA, ${ }^{49}$ but also amplifies intracellular ROS signal. However, this ROS induction does not differentiate between tumor and normal cells, thus exerts obvious toxic side-effects on normal tissues and organs as well. ${ }^{50-52}$ The MSN@GO-HA could concentrate $\mathrm{CA}$ and DOX in the target tissue as much as possible, thereby reducing the oxidation failure of CA and toxicity of DOX. Moreover, the above results also revealed that the effects of $\mathrm{CA}$ and DOX on the ROS level and mitochondrial function in $\mathrm{MCF}-7$ cells were concentration-dependent. When the concentration of DOX was set to $40 \mu \mathrm{g} / \mathrm{mL}$, the concentration of CA was greater than $200 \mu \mathrm{g} / \mathrm{mL}$ according to the mass ratio of CA to DOX (about 6:1) in the co-loaded preparations, thus exerting greater effects on the above experiments than that of the co-loaded preparations calibrated with the CA concentration of $200 \mu \mathrm{g} / \mathrm{mL}$ (the DOX concentration was less than $40 \mu \mathrm{g} / \mathrm{mL}$ in the same preparation).

Studies have demonstrated that the elevated ROS levels in mitochondria would activate the opening of the mitochondrial permeability transition pore (MPTP), thus promoting the cytochrome $\mathrm{C}(\mathrm{CytC})$ release, which would first activate Caspase-9 through the formation of a multimer with apoptosis protease activating factor 1 (Apaf-1), followed by the activation of Caspase-3. Once activated, Caspase- 3 would disable the function of the downstream signaling proteins by deconstructing their structure, finally leading to apoptosis. ${ }^{21,53-56}$ The Caspase-3 and Caspase-9 detection tests indicated that either CA or DOX alone could increase the levels of Caspase-3 and Caspase-9 to a certain extent by affecting the mitochondrial function, and CA was superior to DOX. Moreover, the combination of CA and DOX could significantly increase the levels of Caspase-3 and Caspase-9, thereby accelerating the apoptosis and necrosis of tumor cells. Furthermore, CA inhibiting the synthesis of ATP also enhanced the effects of DOX indirectly on the transcription and translation of DNA. The synergistic effect of CA and DOX together with the introduction of HA modified co-loaded carrier (MSN@GO) further improved the tumor targeting, synergistic effect and reduced the defects of the two therapeutic agents, thus effectively ensuring their treatment dose and effect.

\section{Conclusion}

To sum up, we reported a kind of HA-modified composite nanoparticles, MSN@GO-HA, for the co-delivery of two chemotherapeutics, CA and DOX. The two components of the system, MSN-NH${ }_{2}$ and GO-HA, enabled efficient loading of CA and DOX through the physical adsorption and $\pi-\pi$ conjugated effects, respectively. $\mathrm{MSN}_{\mathrm{CA}} @ \mathrm{GO}_{\mathrm{DOX}}-\mathrm{HA}$ achieved good serum stability and $\mathrm{pH}$-responsive release behavior, thus preventing the oxidation failure of $\mathrm{CA}$ and the systemic toxicity of DOX caused by the advanced release before reaching the tumor tissue. Furthermore, $\mathrm{MSN}_{\mathrm{CA}}$ (a) $\mathrm{GO}_{\mathrm{DOX}}-\mathrm{HA}$ actively targeted to the tumor cells through the "ligand-receptor" affinity between HA and CD44 receptor. CA disrupted the mitochondrial function, which not only selectively increased the intracellular ROS level, so as to 
open the intrinsic apoptotic pathway, but also enhance the efficacy of DOX indirectly via inhibiting ATP synthesis, thus enhancing the final therapeutic effect. Therefore, the establishment of the composite $\mathrm{MSN}_{\mathrm{CA}} @ \mathrm{GO}_{\mathrm{DOx}}-\mathrm{HA}$ nanoparticles effectively improved the synergistic treatment of CA and DOX and reduced their defects, thereby providing references for the design of new composite nanodrug delivery systems.

\section{Acknowledgments}

This work was supported financially by the National Natural Science Foundation of China (No. 81803491), the Natural Science Foundation of Shaanxi Province (No. 2019JQ-320), the Fundamental Research Funds for the Central Universities (No. 3102019smxy002), the Postdoctoral Science Foundation of Shaanxi Province (No. 2018BSHQYXMZZ43), the Graduate Creative Innovation Seed Fund of Northwestern Polytechnical University (No.CX2020259), the undergraduate innovation and entrepreneurship training program of Shaanxi Province (No. S201910699245) and the Innovation Capability Support Program of Shaanxi (No. 2020TD-042). The authors thank the Analytical \& Testing Center of Northwestern Polytechnical University for the help on the characterization.

\section{Disclosure}

The authors report no conflicts of interest for this work.

\section{References}

1. Watanabe T. Chemoradiotherapy and adjuvant chemotherapy for rectal cancer. Int J Clin Oncol. 2008;13(6):488-497. doi:10.1007/s10147008-0849-0

2. Garcia G, Odaimi M. Systemic combination chemotherapy in elderly pancreatic cancer: a review. $J$ Gastrointest Cancer. 2017;48 (2):121-128. doi:10.1007/s12029-017-9930-0

3. Aziz MYA, Abu N, Yeap SK, et al. Combinatorial cytotoxic effects of damnacanthal and doxorubicin against human breast cancer MCF-7 cells in vitro. Molecules. 2016;21(9):15.

4. Zhang HS, Yu M, Zhang HL, et al. Synthesis, characterization and fluorescent properties of water-soluble glycopolymer bearing curcumin pendant residues. Biosci Biotechnol Biochem. 2016;80(8):1451-1458. doi:10.1080/09168451.2016.1171696

5. Banerjee A, Pathak S, Subramanium VD, Dharanivasan G, Murugesan R, Verma RS. Strategies for targeted drug delivery in treatment of colon cancer: current trends and future perspectives. Drug Discov Today. 2017;22(8):1224-1232. doi:10.1016/j. drudis.2017.05.006

6. Ho PC. Combined chemotherapy delivered by nanoparticulate systems: an old concept with modern innovations. Ther Deliv. 2012;3 (12):1363-1368. doi:10.4155/tde.12.111

7. Aryal B, Jeong J, Rao VA. Doxorubicin-induced carbonylation and degradation of cardiac myosin binding protein $\mathrm{C}$ promote cardiotoxicity. Proc Natl Acad Sci USA. 2014;111(5):2011-2016. doi:10.1073/pnas.1321783111

8. Dilnawaz F. Multifunctional mesoporous silica nanoparticles for cancer therapy and imaging. Curr Med Chem. 2019;26(31):5745-5763. doi:10.2174/0929867325666180501101044
9. Zhou J, Yu GC, Huang FH. Supramolecular chemotherapy based on host-guest molecular recognition: a novel strategy in the battle against cancer with a bright future. Chem Soc Rev. 2017;46 (22):7021-7053.

10. Croissant JG, Fatieiev Y, Almalik A, Khashab NM, Silica M. Organosilica nanoparticles: physical chemistry, biosafety, delivery strategies, and biomedical applications. Adv Healthc Mater. 2018;7 (4):75.

11. Bharti C, Nagaich U, Pal AK, Gulati N. Mesoporous silica nanoparticles in target drug delivery system: a review. Int $J$ Pharm Investig. 2015;5(3):124-133. doi:10.4103/2230-973X.160844

12. Cavallaro G, Lazzara G, Fakhrullin R. Mesoporous inorganic nanoscale particles for drug adsorption and controlled release. Ther Deliv. 2018;9(4):287-301. doi:10.4155/tde-2017-0120

13. Yang K, Feng LZ, Shi XZ, Liu Z. Nano-graphene in biomedicine: theranostic applications. Chem Soc Rev. 2013;42(2):530-547.

14. Tang YX, Hu H, Zhang MG, et al. An aptamer-targeting photoresponsive drug delivery system using "off-on" graphene oxide wrapped mesoporous silica nanoparticles. Nanoscale. 2015;7 (14):6304-6310.

15. Kong RM, Zhang XB, Chen Z, Tan WH. Aptamer-assembled nanomaterials for biosensing and biomedical applications. Small. 2011;7 (17):2428-2436.

16. Yi M, Yang S, Peng Z, et al. Two-photon graphene oxide/aptamer nanosensing conjugate for in vitro or in vivo molecular probing. Anal Chem. 2014;86(7):3548-3554. doi:10.1021/ac5000015

17. Pourjavadi A, Tehrani ZM, Jokar S. Functionalized mesoporous silica-coated magnetic graphene oxide by polyglycerol-g-polycaprolactone with $\mathrm{pH}-$ responsive behavior: designed for targeted and controlled doxorubicin delivery. $J$ Ind Eng Chem. 2015;28:45-53. doi:10.1016/j.jiec.2015.01.021

18. Feng LZ, Li KY, Shi XZ, Gao M, Liu J, Liu Z. Smart pH-responsive nanocarriers based on nano-graphene oxide for combined chemo- and photothermal therapy overcoming drug resistance. Adv Healthc Mater. 2014;3(8):1261-1271. doi:10.1002/adhm.201300549

19. Sreejith S, Ma X, Zhao YL. Graphene oxide wrapping on squaraine-loaded mesoporous silica nanoparticles for bioimaging. J Am Chem Soc. 2012;134(42):17346-17349. doi:10.1021/ja305352d

20. Yoo W, Yoo D, Hong E, et al. Acid-activatable oxidative stress-inducing polysaccharide nanoparticles for anticancer therapy. J Control Release. 2018;269:235-244. doi:10.1016/j. jconrel.2017.11.023

21. Ka H, Park HJ, Jung HJ, et al. Cinnamaldehyde induces apoptosis by ROS-mediated mitochondrial permeability transition in human promyelocytic leukemia HL-60 cells. Cancer Lett. 2003;196 (2):143-152. doi:10.1016/S0304-3835(03)00238-6

22. Dong K, Lei QY, Qi HF, et al. Amplification of oxidative stress in MCF-7 cells by a novel pH-responsive amphiphilic micellar system enhances anticancer therapy. Mol Pharm. 2019;16(2):689-700. doi:10.1021/acs.molpharmaceut.8b00973

23. Yun M, Lee D, Park MN, et al. Cinnamaldehyde derivative (CB-PIC) sensitizes chemo-resistant cancer cells to drug-induced apoptosis via suppression of MDR1 and its upstream STAT3 and AKT signalling. Cell Physiol Biochem. 2015;35(5):1821-1830. doi:10.1159/000373993

24. El-Readi MZ, Mazzanti G, Wink M. $\alpha$-hexylcinnamaldehyde synergistically increases doxorubicin cytotoxicity towards human cancer cell lines. Anticancer Res. 2016;36(7):3347-3351.

25. Abbasi A, Hajialyani M, Hosseinzadeh L, et al. Evaluation of the cytotoxic and apoptogenic effects of cinnamaldehyde on U87MG cells alone and in combination with doxorubicin. Res Pharm Sci. 2020;15(1):26-35. doi:10.4103/1735-5362.278712

26. Hong SH, Kim J, Kim JM, et al. Apoptosis induction of 2 'hydroxycinnamaldehyde as a proteasome inhibitor is associated with ER stress and mitochondrial perturbation in cancer cells. Biochem Pharmacol. 2007;74(4):557-565. doi:10.1016/j. bcp.2007.05.016 
27. Lee K, Kwon BM, Kim K, et al. Plasma pharmacokinetics and metabolism of the antitumour drug candidate 2'-benzoyloxycinnamaldehyde in rats. Xenobiotica. 2009;39(3):255-265. doi:10.1080/004982508026 50069

28. Moreira AC, Branco AF, Sampaio SF, et al. Mitochondrial apoptosis-inducing factor is involved in doxorubicin-induced toxicity on H9c2 cardiomyoblasts. Biochim Biophys Acta. 2014;1842 (12):2468-2478. doi:10.1016/j.bbadis.2014.09.015

29. Gilliam LAA, Fisher-Wellman KH, Lin CT, Maples JM, Cathey BL, Neufer PD. The anticancer agent doxorubicin disrupts mitochondrial energy metabolism and redox balance in skeletal muscle. Free Radic Biol Med. 2013;65:988-996. doi:10.1016/j.freeradbiomed.2013.08.191

30. Fan CM, Georgiou KR, Morris HA, et al. Combination breast cancer chemotherapy with doxorubicin and cyclophosphamide damages bone and bone marrow in a female rat model. Breast Cancer Res Treat. 2017;165(1):41-51. doi:10.1007/s10549-017-4308-3

31. Mattheolabakis G, Milane L, Singh A, Amiji MM. Hyaluronic acid targeting of CD44 for cancer therapy: from receptor biology to nanomedicine. J Drug Target. 2015;23(7-8):605-618. doi:10.3109/ 1061186X.2015.1052072

32. Yildiz ZI, Kilic ME, Durgun E, Uyar T. Molecular encapsulation of cinnamaldehyde within cyclodextrin inclusion complex electrospun nanofibers: fast-dissolution, enhanced water solubility, high temperature stability, and antibacterial activity of cinnamaldehyde. J Agric Food Chem. 2019;67(40):11066-11076. doi:10.1021/acs.jafc.9b02789

33. Cui N, Jing JJ, Li M, Qi HF, Wu XL, Lu TL. Electrophoretic deposition of GHK-Cu loaded MSN-chitosan coatings with $\mathrm{pH}$-responsive release of copper and its bioactivity. Mater Sci Eng C. 2019;104:11.

34. Wu HX, Shi HL, Wang YP, et al. Hyaluronic acid conjugated graphene oxide for targeted drug delivery. Carbon. 2014;69:379-389. doi:10.1016/j.carbon.2013.12.039

35. Kim KM, Kim HM, Lee WJ, et al. Surface treatment of silica nanoparticles for stable and charge-controlled colloidal silica. Int J Nanomed. 2014;9:29-40.

36. Gref R, Lück M, Quellec P, et al. 'Stealth' corona-core nanoparticles surface modified by polyethylene glycol (PEG): influences of the corona (PEG chain length and surface density) and of the core composition on phagocytic uptake and plasma protein adsorption. Colloids Surfaces B. 2000;18(3-4):301-313. doi:10.1016/S09277765(99)00156-3

37. Hu XB, Yu Y, Hou WM, Zhou JE, Song LX. Effects of particle size and $\mathrm{pH}$ value on the hydrophilicity of graphene oxide. Appl Surf Sci. 2013;273:118-121. doi:10.1016/j.apsusc.2013.01.201

38. Zhang RY, Wu CH, Wang XM, et al. Enhancement effect of nano Fe3O4 to the drug accumulation of doxorubicin in cancer cells. Mater Sci Eng C. 2009;29(5):1697-1701. doi:10.1016/j. msec.2009.01.021

39. Dong K, Lei QY, Guo RH, et al. Regulating intracellular ROS signal by a dual $\mathrm{pH} /$ reducing-responsive nanogels system promotes tumor cell apoptosis. Int J Nanomed. 2019;14:5713-5728.

40. Hong W, Chen DW, Zhang XJ, et al. Reversing multidrug resistance by intracellular delivery of Pluronic (R) P85 unimers. Biomaterials. 2013;34(37):9602-9614. doi:10.1016/j.biomaterials.2013.08.032

41. Grange C, Geninatti-Crich S, Esposito G, et al. Combined delivery and magnetic resonance imaging of neural cell adhesion moleculetargeted doxorubicin-containing liposomes in experimentally induced Kaposi’s sarcoma. Cancer Res. 2010;70(6):2180-2190. doi:10.1158/ 0008-5472.CAN-09-2821
42. Swain SM, Whaley FS, Ewer MS. Congestive heart failure in patients treated with doxorubicin - a retrospective analysis of three trials. Cancer. 2003;97(11):2869-2879. doi:10.1002/cncr.11407

43. Mahdavi M, Rahmani F, Nouranian S. Molecular simulation of $\mathrm{pH}$-dependent diffusion, loading, and release of doxorubicin in graphene and graphene oxide drug delivery systems. J Mat Chem B. 2016;4(46):7441-7451. doi:10.1039/C6TB00746E

44. Chang WL, Cheng FC, Wang SP, Chou ST, Shih Y. Cinnamomum cassia essential oil and its major constituent cinnamaldehyde induced cell cycle arrest and apoptosis in human oral squamous cell carcinoma HSC-3 cells. Environ Toxicol. 2017;32(2):456-468. doi:10.1002/tox. 22250

45. Strauss M, Hofhaus G, Schröder RR, Kühlbrandt W. Dimer ribbons of ATP synthase shape the inner mitochondrial membrane. EMBO J. 2008;27(7):1154-1160. doi:10.1038/emboj.2008.35

46. Bagkos G, Koufopoulos K, Piperi C. ATP synthesis revisited: new avenues for the management of mitochondrial diseases. Curr Pharm Des 2014;20(28):4570-4579. doi:10.2174/ 1381612819666131230124334

47. Nobili S, Lapucci A, Landini I, Coronnello M, Roviello G, Mini E. Role of ATP-binding cassette transporters in cancer initiation and progression. Semin Cancer Biol. 2020;60:72-95. doi:10.1016/j. semcancer.2019.08.006

48. AlSalim T, Saeed ME, Hadi JS, et al. Cytotoxicity of novel sulfanilamides towards sensitive and multidrug-resistant leukemia cells. Curr Med Chem. 2014;21(23):2715-2725. doi:10.2174/092986 7321666140120120708

49. Yang F, Teves S. S, Kemp CJ, Henikoff S. Doxorubicin, DNA torsion, and chromatin dynamics. Biochim. Biophys. Acta-Rev. Cancer. 2014;1845(1):84-89.

50. Lee YS, Choi YJ, Lee J, Shim DM, Park WY, Seo SW. TP53 alteration determines the combinational cytotoxic effect of doxorubicin and an antioxidantNAC. Tumor Biol. 2017;39(6):9. doi:10.1177/ 1010428317700159

51. Doroshow JH, Esworthy RS, Chu -F-F. Control of doxorubicin-induced, reactive oxygen-related apoptosis by glutathione peroxidase 1 in cardiac fibroblasts. Biochem Biophys Rep. 2020;21:100709. doi:10.1016/j.bbrep.2019.100709

52. Shin HJ, Kwon HK, Lee JH, et al. Doxorubicin-induced necrosis is mediated by poly-(ADP-ribose) polymerase 1 (PARP1) but is independent of p53. Sci Rep. 2015;5:17. doi:10.1038/srep15798

53. Debatin KM. Apoptosis pathways in cancer and cancer therapy. Cancer Immunol Immunother. 2004;53(3):153-159. doi:10.1007/ s00262-003-0474-8

54. Mita MM, Mita AC, Tolcher AW. Apoptosis: mechanisms and implications for cancer therapeutics. Target Oncol. 2006;1(4):197-214.

55. Ghobrial IM, Witzig TE, Adjei AA. Targeting apoptosis pathways in cancer therapy. CA Cancer J Clin. 2005;55(3):178-194.

56. Huang TC, Fu HY, Ho CT, Tan D, Huang YT, Pan MH. Induction of apoptosis by cinnamaldehyde from indigenous cinnamon Cinnamomum osmophloeum Kaneh through reactive oxygen species production, glutathione depletion, and caspase activation in human leukemia K562 cells. Food Chem. 2007;103(2):434-443. doi:10.1016/j.foodchem.2006.08.018 


\section{Publish your work in this journal}

The International Journal of Nanomedicine is an international, peerreviewed journal focusing on the application of nanotechnology in diagnostics, therapeutics, and drug delivery systems throughout the biomedical field. This journal is indexed on PubMed Central, MedLine, CAS, SciSearch ${ }^{\mathbb{R}}$, Current Contents ${ }^{\mathbb{R}} /$ Clinical Medicine, $^{2}$
Journal Citation Reports/Science Edition, EMBase, Scopus and the Elsevier Bibliographic databases. The manuscript management system is completely online and includes a very quick and fair peer-review system, which is all easy to use. Visit http://www.dovepress.com/ testimonials.php to read real quotes from published authors. 